\title{
Genetic Polymorphism in Wine Yeasts: Mechanisms and Methods for Its Detection
}

\author{
José M. Guillamón ${ }^{1 *}$ and Eladio Barrio ${ }^{1,2}$ \\ ' Departamento de Biotecnología de los Alimentos, Instituto de Agroquímica y Tecnología de Alimentos - Consejo Superior \\ de Investigaciones Científicas (CSIC), Valencia, Spain, ${ }^{2}$ Departamento de Genética, Universidad de Valencia, Valencia, Spain
}

\section{OPEN ACCESS}

Edited by:

Gustavo Cordero-Bueso, University of Cádiz, Spain

Reviewed by: Manuel Ramírez,

University of Extremadura, Spain Cristian A. Varela,

Australian Wine Research Institute,

Australia

${ }^{*}$ Correspondence:

José M. Guillamón guillamon@iata.csic.es

Specialty section:

This article was submitted to

Food Microbiology,

a section of the journal

Frontiers in Microbiology

Received: 17 February 2017 Accepted: 19 April 2017

Published: 04 May 2017

Citation:

Guillamón JM and Barrio E (2017) Genetic Polymorphism in Wine Yeasts: Mechanisms and Methods for Its Detection.

Front. Microbiol. 8:806. doi: 10.3389/fmicb.2017.00806
The processes of yeast selection for using as wine fermentation starters have revealed a great phenotypic diversity both at interspecific and intraspecific level, which is explained by a corresponding genetic variation among different yeast isolates. Thus, the mechanisms involved in promoting these genetic changes are the main engine generating yeast biodiversity. Currently, an important task to understand biodiversity, population structure and evolutionary history of wine yeasts is the study of the molecular mechanisms involved in yeast adaptation to wine fermentation, and on remodeling the genomic features of wine yeast, unconsciously selected since the advent of winemaking. Moreover, the availability of rapid and simple molecular techniques that show genetic polymorphisms at species and strain levels have enabled the study of yeast diversity during wine fermentation. This review will summarize the mechanisms involved in generating genetic polymorphisms in yeasts, the molecular methods used to unveil genetic variation, and the utility of these polymorphisms to differentiate strains, populations, and species in order to infer the evolutionary history and the adaptive evolution of wine yeasts, and to identify their influence on their biotechnological and sensorial properties.

Keywords: SNP, insertions, deletions, ploidy changes, interspecific hybridization, gene horizontal transfer, PCR-based methods, NGS

\section{INTRODUCTION}

During the advent of agriculture, humans learnt to put to good use spoiled fruit juices that spontaneously fermented in order to produce alcoholic beverages (Mortimer, 2000), of which grape wine is one of the oldest (McGovern et al., 1997). Alcoholic fermentation of grape must to wine is a complex process that involves the sequential development of microorganisms, mainly yeasts, but also filamentous fungi, lactic acid bacteria and acetic acid bacteria (Pretorius, 2000). Several dozens of yeast species may be present in early wine fermentation stages. However, the yeast population progressively becomes dominated by yeasts that belong to the Saccharomyces genus, mainly Saccharomyces cerevisiae as alcohol concentration increases (Fleet and Heard, 1993).

Yeasts from the Saccharomyces genus exhibit distinctive physiological properties that are not found in other yeasts (Vaughan-Martini and Martini, 2011). The most important is their excellent ability to ferment sugars vigorously to produce alcohol under both aerobic and anaerobic conditions (Piškur et al., 2006; Dashko et al., 2014). This aptitude allows them to quickly colonize sugar-rich substrates and outcompete other yeasts that are much less tolerant to the ethanol and heat produced during fermentation (Goddard, 2008; Salvadó et al., 2011). Consequently, wine 
S. cerevisiae strains are highly specialized organisms that have evolved to utilize the different environments or ecological niches provided by human activity. This process can be described as "unaware domestication" and is responsible for the peculiar genetic characteristics of these yeasts (Fay and Benavides, 2005; Liti et al., 2009; Almeida et al., 2015). S. cerevisiae strains that exhibit high ethanol tolerance and excellent fermentative ability are extensively used in winemaking as starter cultures. However, a side-effect of the widespread use of these commercial starter cultures is the elimination of native microbiota, which might result in wines with similar analytical and sensory properties, depriving them from the variability and diversity that define the typicality of a wine. Nonetheless, a way of balancing control and yeast population diversity during wine fermentation is the selection of non-Saccharomyces yeasts with optimal oenological traits.

Thus, in recent years, other wine yeast species attracted much interest for their potential application to solve new challenges in the winemaking industry generated by consumer demands of aromatic wines with lower ethanol contents, or due to the modification of the composition and properties of grape must because of climate change (Jones et al., 2005). New yeast starters from other Saccharomyces species, and from non-Saccharomyces species, are being developed to be used in mixed cultures or in sequential inoculations in order to direct fermentations to obtain wines with higher glycerol concentration and aroma intensity, and lower ethanol and acetic acid, contents. In this way, alternative Saccharomyces species, such as S. uvarum and S. kudriavzevii, and their hybrids with $S$. cerevisiae, exhibit good fermentative capabilities at low temperature, and produce wines with lower alcohol concentration, higher glycerol amounts, and excellent aromatic profiles (González et al., 2007; Gamero et al., 2013; Peris et al., 2016), properties of great interest for the wine industry. Additionally the use of non-Saccharomyces species, such as Metschnikowia pulcherrima, in co-cultures with $S$. cerevisiae has been suggested as an enological practice to reduce ethanol contents in wine (Contreras et al., 2014; Morales et al., 2015). The use of Candida zemplinina, Hanseniaspora vineae, and Torulaspora delbrueckii yeasts has been proposed to improve the organoleptic properties of wines (Renault et al., 2009; Medina et al., 2013; Jolly et al., 2014).

The study of natural yeast isolates, both at interspecific and intraspecific level, has revealed a great phenotypic diversity, which is explained by a corresponding genetic variation. Thus, the mechanisms involved in promoting these genetic changes are the main engine driving yeast biodiversity. Currently, an important task to understand biodiversity, population structure and evolutionary history of wine yeasts is the study of the molecular mechanisms involved in yeast adaptation to the industrial process, and on remodeling the genomic features of wine yeast, unconsciously selected since the advent of winemaking (Barrio et al., 2006; Marsit and Dequin, 2015). Genetic variation is the ultimate source of heritable variation, acted upon by evolutionary forces such as selection and genetic drift. The neo-Darwinian theory of evolution by natural selection was founded on the notion that natural populations hold abundant genetic polymorphisms to respond to selection.
This genetic variability is due to the occurrence of different alleles originated by mutation and homologous recombination. Adaptation is then the result of the gradual accumulation of minor changes in allele frequencies due to the action of natural selection. Different molecular approaches have shown that mutations include not only the generation of new alleles by nucleotide changes, but also the acquisition of new genes or the formation of radically different alleles originated by other mechanisms.

This article reviews the mechanisms involved in generating genetic polymorphisms in yeasts, the molecular methods used to unveil genetic variation, and the utility of these polymorphisms to differentiate strains, populations, and species in order to infer the evolutionary history and the adaptive evolution of wine yeasts, and to identify their influence on their biotechnological and sensorial properties.

\section{MECHANISMS INVOLVED IN THE GENERATION OF YEAST GENETIC POLYMORPHISMS}

Yeast genomes are exposed to dynamic mechanisms generating genetic polymorphisms with different evolutionary consequences. These mechanisms can be classified in single nucleotide polymorphisms (SNPs), short sequence insertions or deletions, recombination and gene conversion, short tandem duplications, gene and segmental duplications, gross chromosomal rearrangements (GCRs), ploidy changes and interspecific hybridization (Figure 1).

\section{Single Nucleotide Polymorphisms}

Single nucleotide polymorphisms are single nucleotide positions in DNA at which different sequence alternatives (alleles) exist in individuals of the same population or species (Brookes, 1999). More broadly speaking, they correspond to the single nucleotide substitutions or small nucleotide insertion-deletions (indels) generated by point mutation due to errors in DNA replication or DNA repair. Although SNPs are less variable than microsatellites (see below), they represent the most widespread type of sequence variation in genomes. SNPs are presently inferred mainly from single gene, multilocus, and genome sequence comparisons (Ben Ari et al., 2005; Fay and Benavides, 2005; Liti et al., 2009; Hyma and Fay, 2013).

Nucleotide polymorphisms have also emerged as valuable genetic markers to reveal the evolutionary history of populations. In this way, SNPs from genome sequence analyses have been used to determine phylogenetic relationships among S. cerevisiae strains (Liti et al., 2009; Almeida et al., 2015; Gallone et al., 2016) and other Saccharomyces species (Almeida et al., 2014; Peris et al., 2014).

Nucleotide polymorphisms in coding regions or regulatory sequences may change protein structure and function or modify gene expression. Therefore, sequence analyses can also be useful to unveil adaptive evolution in yeasts. In their study, Aa et al. (2006) also reported the presence of a greater replacement polymorphism in gene SSU1, which provided evidence for 
A Single nucleotide polymorphisms

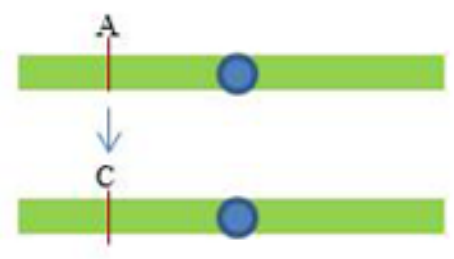

B insertion/deletion (InDels)

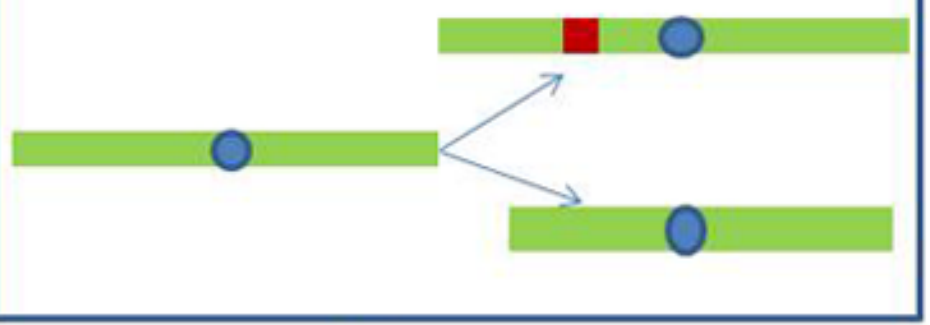

D Ectopic recombination

C Homologous or reciprocal recombination
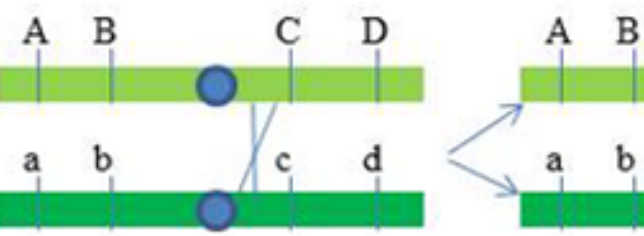
c d

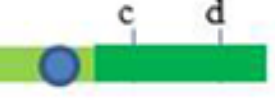

C D
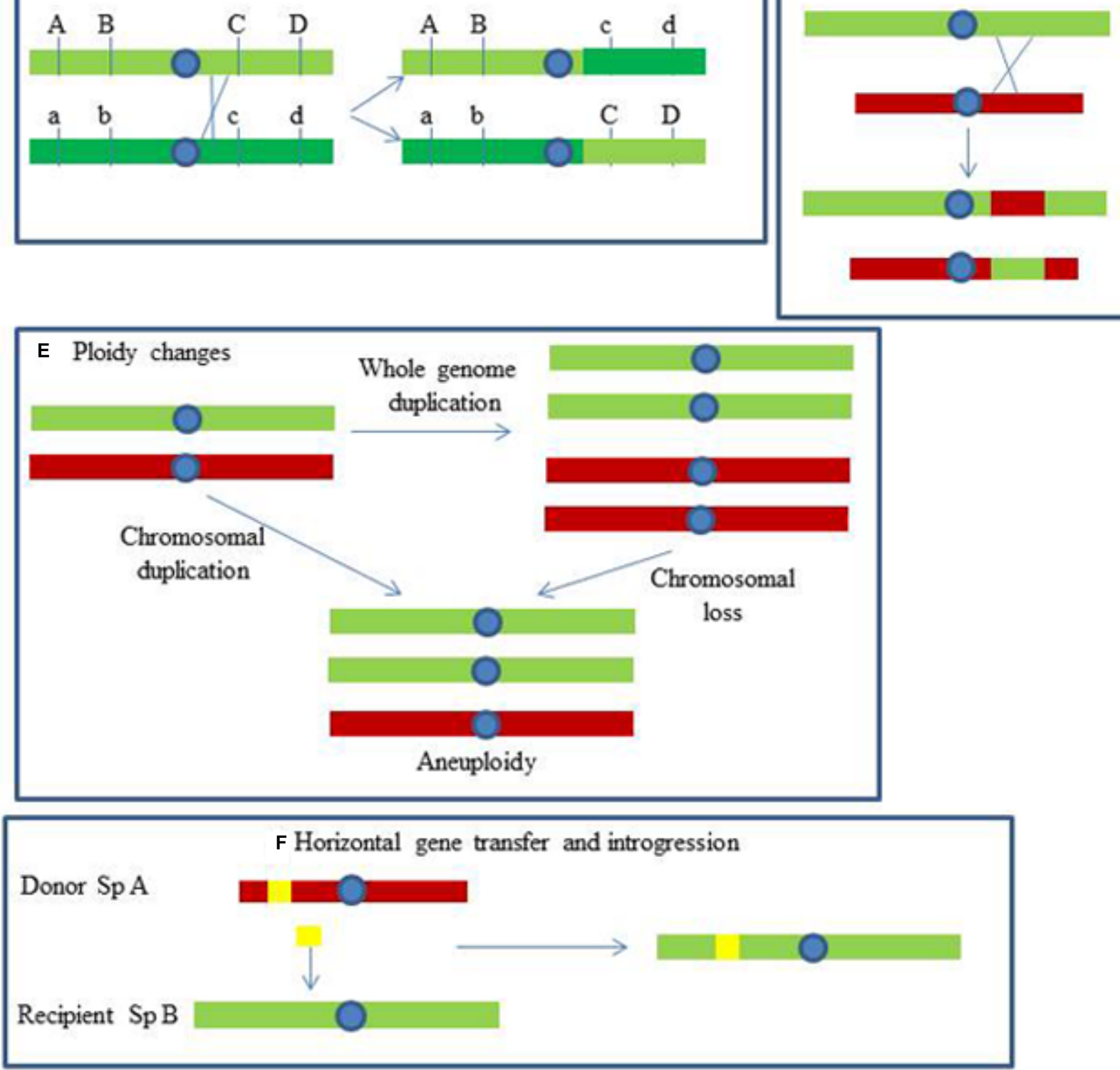

FIGURE 1 | Mechanisms involved in the generation of yeast genetic polymorphism. (A) Single nucleotide polymorphisms: changes in single nucleotides. (B) InDels: insertion and deletion events of relatively short pieces of DNA. (C) Homologous or reciprocal recombination: gene conversion by crossing-over between homologous chromosomes. (D) Ectopic recombination: unequal crossing-over between non-homologous loci. (E) Ploidy changes: the whole genome, or large parts, is duplicated or lost. (F) Horizontal gene transfer: transfer of genes by alternative means to sexual reproduction (adapted from Steensels et al., 2014). 
diversifying selection by acting on its protein product, a sulfite exporter involved in sulfite resistance, as a response to the selective pressure imposed by employing sulfite in winemaking as a bactericide.

Nucleotide divergences in promoter regions may have major effects on gene expression levels, which can also be affected by nucleotide changes in the coding regions of transcription factor genes. In a comparative genome analysis searching for promoters with divergent function, Engle and Fay (2012) identified changes in both the coding and upstream non-coding sequences of yeast transcription factor gene $F Z F 1$, which resulted in differences to confer sulfite resistance. Non-coding changes affected transcription factor expression, whereas coding changes affected the expression of SSU1, the sulfite pump.

In some cases, polymorphisms have been demonstrated as being involved in generating phenotypic variation in yeast properties of biotechnological interest. By way of example, Marullo et al. (2007) studied the genetic basis for variations in acetic acid production in wine strains by quantitative trait loci (QTL) mapping. They showed that this variation was due to a non-synonymous single-nucleotide polymorphism in ASP1. The corresponding amino acid replacement abolished the catalytic activity of encoded asparaginase type I, which affected nitrogen assimilation, the $\mathrm{CO}_{2}$ production rate and acetic acid production. Guillaume et al. (2007) also described nucleotide substitutions in gene HXT3, which encodes one of the hexose transporters, that resulted in improved fructose assimilation during wine fermentation. Oliveira et al. (2014) observed that non-synonymous nucleotide divergences between GPD1 genes from $S$. kudriavzevii and $S$. cerevisiae could explain differences in the $V_{\max }$ of glycerol-3-phosphate dehydrogenases, responsible for higher glycerol production in S. kudriavzevii (Arroyo-López et al., 2010).

In some extraordinary cases, missense and nonsense mutations can take an adaptive value. Will et al. (2010) showed that independent loss in $S$. cerevisiae strains of paralogous $A Q Y 1$ and $A Q Y 2$ genes, which encode the water-transporter aquaporins involved in freeze-thaw tolerance, provided a major fitness advantage in highly sugar-rich environments.

\section{Microsatellites}

Microsatellites, simple sequence repeats (SSR) or short tandem repeats (STR) are direct duplications of short motifs of nucleotides arranged in tandem, which display variation in the number of repeats. The high polymorphism of microsatellites is due to the relatively high motif insertion/deletion (InDels) rates generated by slipped-strand mispairing between contiguous repeats during replication, and by unequal crossover between motifs.

The sequence that surrounds the repeat region is usually conserved, and allows the design of PCR primers to amplify the repeat region. Differences in the number of repeats are identified as length polymorphisms in PCR products by using high-resolution electrophoresis, including automatic DNA sequencers. Microsatellite codominant polymorphisms have proven very useful for strain discrimination (GonzálezTechera et al., 2001; Pérez et al., 2001; Legras et al., 2005;
Masneuf-Pomarède et al., 2007), for the genetic analysis of yeast populations (Ayoub et al., 2006; Legras et al., 2007), and to also determine levels of heterozygosity and ploidy (Bradbury et al., 2006; Katz Ezov et al., 2006).

Microsatellites variation may affect phenotypic traits only when located in regulatory and coding regions. With yeasts, the most important source of gene elongation is the presence of codon repeats generated by trinucleotide expansions. No correlation between these expansions and variation in yeast traits of industrial interest has yet been demonstrated. However, a higher frequency of codon repeats in transcription factors and protein kinases has been described in yeasts (Richard and Dujon, 1997; Albà et al., 1999). Changes in the length of repeats in such cellular components of the cell signaling system could alter their biochemical properties, and therefore readjust their interactions with regulatory DNA regions or with other transcription factors, which could provide evolutionary divergence (Albà et al., 1999; Malpertuy et al., 2003).

\section{Meiotic, Mitotic Recombination, and Levels of Heterozygosity}

Homologous or reciprocal recombination and gene conversion due to equal crossing-over between homologous chromosomes are the main mechanisms that generate new combinations of mutations. A non-reciprocal recombination due to unequal crossing-over is the source of the duplications, deletions, and translocations that may be involved in the generation of novelties, as reported in the following sections.

In diploid Saccharomyces yeasts, the frequency and nature of recombination during sexual, and also asexual, reproduction have an important impact on their patterns of variability. Recombination occurs during both meiosis and mitosis, although meiotic recombination is about 1000 times more frequent. The analysis of recombination rates and linkage disequilibrium using molecular markers provides interesting information about sexual reproduction frequency in yeasts (Koufopanou et al., 2006; Kuehne et al., 2007; Magwene et al., 2011; Gallone et al., 2016).

Mortimer (2000) observed that natural populations $S$. cerevisiae from wine fermentations and vineyards were diploid, homothallic and showed a low genetic diversity correlated with their high fertility. These observations led the authors to propose a mechanism of evolution for these wine yeasts, named as "genome renewal". This mechanism is based on the ability of homothallic haploid S. cerevisiae cells to switch their mating type during mitosis, followed by a motherdaughter mating. This way, strains of S. cerevisiae, accumulating heterozygous recessive mutations during long periods of asexual reproduction, can change to completely homozygous diploids, except for the MAT locus, after a single sexual cycle followed by a homothallic switching of the haploid spores. This process, called haploselfing or autodiploidization, promotes the action of selection, by removing recessive deleterious genes and fixing recessive beneficial alleles, thereby enabling yeasts to adapt efficiently to changing environmental conditions. However, mitotic recombination or gene conversion during vegetative growth (Puig et al., 2000) as well as break-induced replication 
(Pâques and Haber, 1999) also promote loss of heterozygosity (LOH) in diploid wine S. cerevisiae cells (Ramírez et al., 2004). The direction of the $\mathrm{LOH}$ is asymmetrical in heterozygous yeasts due to the mechanisms involved, but the speed of the process increases as a consequence of the higher viability of the new homozygous yeasts with respect to the original heterozygous cells, which promotes a rapid asymmetric evolution in wine yeasts (Ambrona et al., 2005).

Ruderfer et al. (2006) developed a method to estimate the outcrossing rate in $S$. cerevisiae from whole-genome sequences from three strains and one of their sibling species, S. paradoxus. Based on recombination patterns, they estimated that the outcrossing rate was very low in yeasts as it occurred only once every 50000 divisions, which suggested that sex in yeast primarily involves inbreeding via intratetrad mating or haploselfing.

Many population genomic studies (Liti et al., 2009; Almeida et al., 2015; Strope et al., 2015) were based on homozygous strains derived from monosporic cultures, which make impossible to characterize the genome heterozygosity. Nonetheless, the presence of clinical and industrial mosaic strains suggested a significant admixture between $S$. cerevisiae lineages.

Sequencing of new clinical, environmental, and industrial isolates of S. cerevisiae unveiled a high number of heterozygous positions across the genomes of clinical and industrial yeasts (Argueso et al., 2009; Akao et al., 2011; Borneman et al., 2011; Magwene et al., 2011; Gallone et al., 2016) in contrast to S. cerevisiae isolated from wild environments such as oak forests from North America and Asia, which show very low levels of heterozygosity (Kuehne et al., 2007; Wang et al., 2012). Magwene et al. (2011) proposed that the high levels of heterozygosity observed in clinical and industrial strains most likely resulted from outcrossing between genetically diverse lineages, mediated by unaware strain trafficking due human activity. In addition to the presence of mosaic monosporic strains (Liti et al., 2009), this is also supported by the observation of two populations of S. cerevisiae, native and introduced wine strains, coexisting and interbreeding in Cachaça fermentations (Badotti et al., 2014).

Yeast outcrossing likely occurs in natural environments because sexual reproduction has not been observed in fermentation environments (Puig et al., 2000), and several authors (Pulvirenti et al., 2002; Stefanini et al., 2016b) showed that the insect gut provides the appropriate conditions for sporulation, germination, and mating of Saccharomyces strains.

Magwene et al. (2011) also proposed that these high levels of heterozygosity coupled with clonal expansion and selfing during rare sexual cycles generate a very large number of new homozygous allelic combinations facilitating rapid adaptation to the novel environments created by human activity. The lower levels of heterozygosity in wine yeasts compared to other industrial yeasts, such as brewing yeasts, suggest that these rare sexual cycles, favored by nutrient depletion, seem to be more frequent in wine yeasts (Borneman et al., 2016; Gallone et al., 2016). However, Ambrona and Ramírez (2007) observed after sporulation of wine yeasts that the frequency of mating between cells from the same ascus, favored by physical proximity, was higher than haploselfing and than mating between germinated haploid cells from different tetrads. This mating restriction slowed down the $\mathrm{LOH}$ process of the wine yeast population, maintaining the heterozygosity lower than would be expected by outcrossing but higher than expected under the Mortimer genome renewal model.

\section{Gene and Segmental Duplications}

Gene duplication is the most important source of new genes in eukaryotes. Paralogs are redundant gene copies generated by duplication. Paralogs are unrestricted to preserve their original function and, therefore, can undergo divergent evolution resulting in novel gene functions.

Gene duplications can be produced by different mechanisms to result in the duplication of a single gene or group of adjacent genes (Koszul et al., 2006) in chromosome duplication, called aneuploidy (Hughes et al., 2000), or in the duplication of the whole genome content, called polyploidy (Wolfe and Shields, 1997).

In some cases, redundant genes can be retained if there is an evolutionary advantage to having extra dose repetitions. In others, one duplicate is free to accumulate mutations because only one of the duplicates is under purifying selection due to constraints to preserve the ancestral function. The classical Dobzhansky-Muller model, of generation of novel genes by duplication, postulates that a pair of paralogs is preserved if one of the copies gains a new function while the other maintains the original role. Nevertheless, this process, called neofunctionalization, is expected to be particularly unusual because beneficial mutations resulting in a new function are very rare comparing to loss-of-function mutations, which can be neutrally fixed in the unrestricted copy. As a result, the redundant duplicate finally becomes a non-functional gene, a process known as nonfunctionalization. According to the classical model, the presence of paralogous genes in the genome would be rare in the long term, however, the sequencing of complete yeast genomes showed that the preservation of duplicates is quite frequent (Wagner, 1998).

Force et al. (1999) suggested an alternative mechanism to explain the retention of paralogous genes. This process, called sub-functionalization, requires an ancestral gene with more than one function, which are independent lost in the paralogous genes by complementary degenerative mutations. This model requires that both duplicates complement their preserved subfunctions to produce the full patterns of activity of the ancestral gene. Subsequently, the adaptive evolution can promote the subfunctional specialization of each paralogous gene.

One of the best known examples of subfunctionalization in yeasts is the GAL1-GAL3 paralogous pair, present in Saccharomyces species (Hittinger and Carroll, 2007). The GAL1 gene codes for a galactokinase that catalyzes the phosphorylation of $\alpha$-D-galactose to $\alpha$-D-galactose-1-phosphate in the first step of galactose catabolism, while the galactose-inducible GAL3 gene encodes a transcriptional regulator involved in activation of the GAL genes, including GAL1, in response to galactose. Kluyveromyces lactis possesses one single GAL1 gene coding for a protein with both functions, transcriptional regulator and galactokinase. The phylogenetic analysis of their sequences indicates that Saccharomyces GAL1-GAL3 genes duplicated 
after the divergence of $K$. lactis GAL1, and subsequently, each paralogous gene specialized by subfunctionalization in one of the original functions.

The most frequent events of gene duplications are those that involve a single gene or group of adjacent genes, called segmental duplication. Different mechanisms have been postulated to explain the origin of single-gene and segmental tandem duplications. The critical step lies in the origin of first tandem duplication, which requires the presence of similar nucleotide sequences to flank the duplicated region. These similar sequences may also be provided by transposable elements. An ectopic recombination between homologous chromosomes, or an unequal sister chromatide exchange at similar sequences, also results in genome region duplications. Subsequent duplications can occur by unequal non-homologous recombination between paralogous repeats (Zhao et al., 2014), which gives rise to tandemly repeated multigene families.

Yeast genomes encode hundreds of multigene families with three or more duplicated genes, which indicate that successive single gene or segmental duplications should have occurred. A comparative genome analysis (Dujon et al., 2004) reveled that tandem gene duplications are very frequent, and have occurred during the evolution of hemiascomycetous yeasts.

Different examples of segmental duplications are dispersed throughout the genome. One of them is the CUP 1 tandem cluster, located on chromosome VIII, that encodes a copper metallothionein involved in cupper resistance (Welch et al., 1983). Gene copy number variations were generated by unequal non-homologous recombination (Zhao et al., 2014), and are clearly associated with cupper resistance differences (Warringer et al., 2011).

Other gene families are in the subtelomeric regions located nearby chromosome telomeres. Most subtelomeric gene families encode proteins involved in cell membrane and cell wall components, such as lectin-like proteins (FLO genes), sugar transporters $(H X T)$, genes related to cell-cell fusion $(P R M)$, and the assimilation and utilization of nutrients (GAL, MAL, SUC, and PHO), etc. (Carlson and Botstein, 1983; Ness and Aigle, 1995; Liti and Louis, 2005; Voordeckers et al., 2012).

Although these genes are not essential, they can be important for yeast adaptation to new environmental conditions. This way, genomic churning due to an ectopic recombination between repeated subtelomeric regions plays a key role in rapidly creating phenotypic diversity over evolutionary time, which favors the rapid adaptation of yeasts to industrial environments (Brown et al., 2010; Christiaens et al., 2012; Voordeckers et al., 2012).

\section{Chromosomal Rearrangements}

The analysis of chromosomal DNA by pulse field gel electrophoresis (PFGE) has revealed important chromosome length polymorphisms in yeasts (Bidenne et al., 1992; Querol et al., 1992; Schütz and Gafner, 1994; Nadal et al., 1999). These polymorphisms are due to GCRs, such as translocations, inversions, duplications, and deletions of large chromosomal regions.

The comparative analysis of chromosomes and genomes (Fischer et al., 2000; Infante et al., 2003; Kellis et al., 2003;
Dunn et al., 2005) has shown that duplicated genes, transposable elements and dispersed tRNA-encoding genes are found at chromosomal breakpoints, which supports unequal non-homologous recombination as the mechanism implicated in the origin of GCR. Actually, Ty elements or $\delta$-LTRs are well known as favoring genome instability by ectopic recombination in yeasts (Rachidi et al., 1999; Infante et al., 2003). Unequal non-homologous recombination between sequences of high similarity present in non-homologous genes, between duplicated genes, or between Ty retrotransposons could generate evolutionary novelties, such as new chimerical genes with a modified function or with changes in their regulation (Christiaens et al., 2012; Marsit et al., 2015).

Industrial yeasts exhibit GCR associated to differences in physiological properties of industrial importance (Codón and Benítez, 1995), which is indicative of their potential role in the adaptation of yeasts to industrial environments. As examples, the fact that the same translocation in a region adjacent to CIT1, involved in tricarboxylic acid cycle regulation, repeats in different strains that have evolved under growth in glucoselimited chemostats is indicative of its adaptive value (Dunham et al., 2002). Competition experiments between S. cerevisiae strains with artificial translocations under different physiological conditions (Colson et al., 2004) have shown that translocated strains consistently outcompete the reference strain with no translocation.

Pérez-Ortín et al. (2002) demonstrated that the translocation between $S$. cerevisiae chromosomes VIII and XVI, found frequently in wine strains, was generated by an ectopic recombination between genes ECM34, a gene of unknown function, and SSU1, a gene encoding a sulfite pump, and resulted in a chimerical gene that confers greater resistance to sulfite, a preservative used during winemaking (Figure 2A). This recombination resulted in a new SSU1 promoter that contained four repeats of a 76-bp sequence with putative binding sites for the transcription activator Fzf1p (Figure 2B). This translocation produced an enhanced expression for SSU1. These authors reported a perfect association between the sulfite resistance and the number of 76-bp repeated regions in the SSU1 promoter (Figure 2C). In a recent QTL analysis study (Zimmer et al., 2014), another translocation between chromosomes XV and XVI has been related with a higher SSU1 expression. This translocation is due to an ectopic recombination between the promoter regions of the genes $A D H 1$ and SSU1, and also produces an increase in the expression of SSU1 during the first hours of alcoholic fermentation.

Chromosomal rearrangements are also involved in the postzygotic reproductive isolation between Saccharomyces species (Ryu et al., 1998). Although translocations may contribute to isolation (Delneri et al., 2003), they do not account by themselves for the isolation levels observed among Saccharomyces species (Fischer et al., 2000; Liti et al., 2006).

\section{Ploidy Changes}

Aneuploidy, i.e., change in chromosome copy numbers, is originated by chromosomal non-disjunction during meiosis or 
A

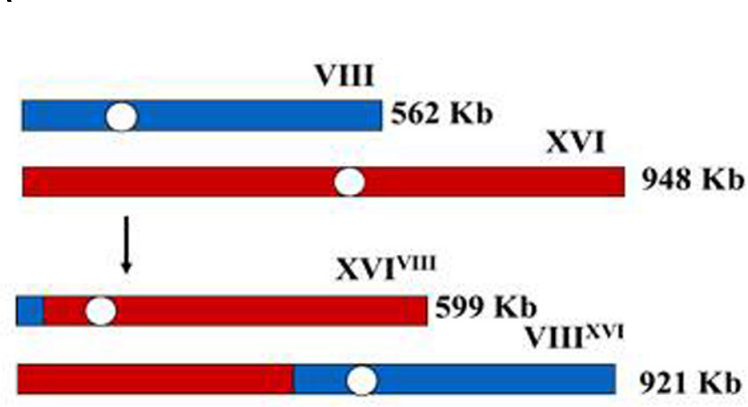

B

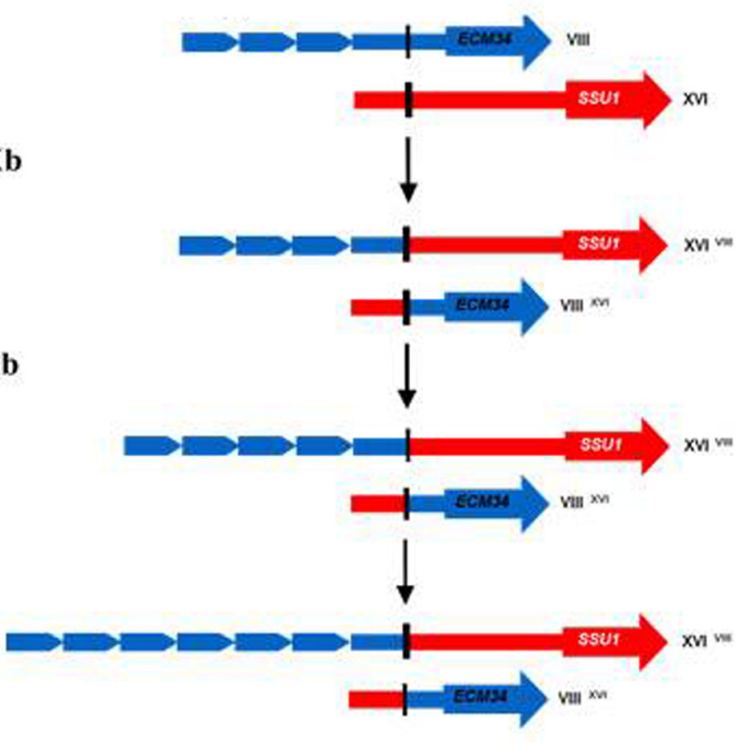

C

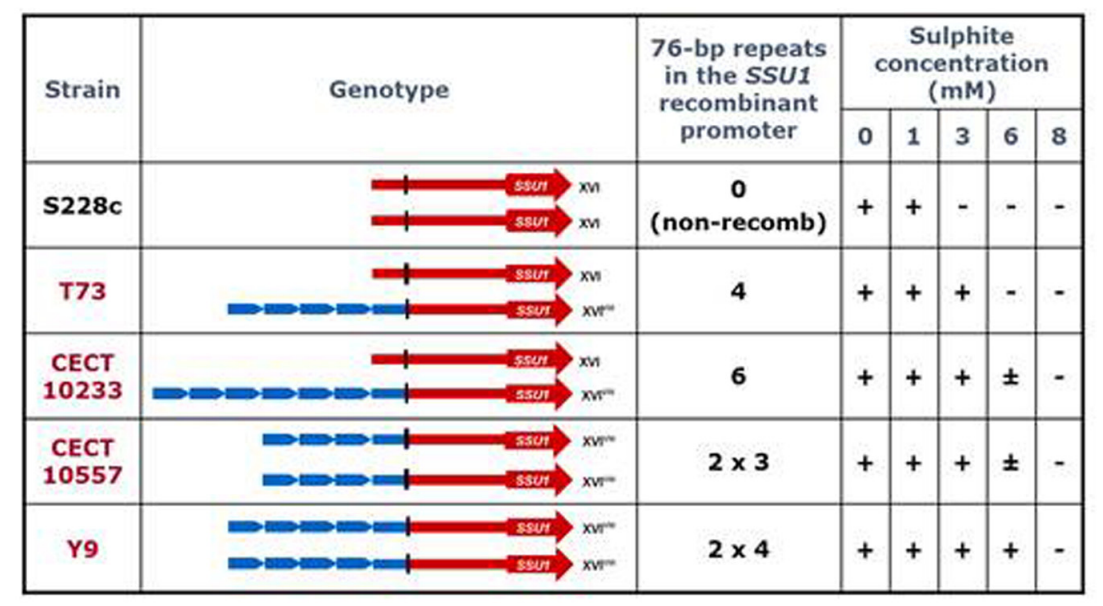

FIGURE 2 | Mechanism involved in wine yeast tolerance to sulfite: the gene SSU1, a paradigm of adaptive genome rearrangement. (A) Reciprocal translocation between chromosomes VIII and XVI observed in wine yeast strains. (B) Organization of the ECM34 and SSU1 non-recombinant alleles and their corresponding recombinant variants obtained by an illegitimate crossing-over. (C) Sulfite tolerance of yeast strains exhibiting different numbers of repeats of a 76-bp region in the recombinant SSU1 promoter (adapted from Pérez-Ortín et al., 2002).

mitosis, and generate a disproportion of gene products and the disruption of their interactions. Although it is one of the causes of their low sporulation levels, aneuploidy is, in general, tolerated by industrial yeasts and has been seen as an advantageous trait in yeasts because a higher number of gene copies may allow them to adapt to changing environments (Bakalinsky and Snow, 1990; Guijo et al., 1997).

Aneuploidies were detected originally by classical genetic analyses. Although most laboratory Saccharomyces strains appeared as diploid, higher aneuploidy levels have been described for certain industrial strains (Bakalinsky and Snow, 1990; Martínez et al., 1995; Guijo et al., 1997; Gallone et al., 2016).
However, the development of array karyotyping (aCGH) and genome sequencing easily allowed the detection of whole chromosome aneuploidies in yeasts with contrasting results for wine strains. In this way, Infante et al. (2003) showed that flor yeasts were aneuploid for a few different chromosomes. However, in a similar study, Dunn et al. (2005) observed no aneuploidies in several commercial wine strains, including two of those previously described as aneuploid (Bakalinsky and Snow, 1990). Flow cytometry and microsatellite analyses of commercial wine yeasts have shown that most are diploid or almost diploid (Ayoub et al., 2006; Bradbury et al., 2006; Legras et al., 2007). This new evidence suggests that aneuploidy in wine strains is much 
less frequent than in other industrial strains such as brewing yeasts (Gallone et al., 2016).

The sequencing of the first $S$. cerevisiae complete genome revealed the presence of 376 duplicated genes in 55 large regions, which led Wolfe and Shields (1997) to postulate an ancient whole genome duplication event occurred in an ancestor of S. cerevisiae after its divergence from K. lactis, about 100-200 million years ago.

Genome duplication, or polyploidization, in yeasts can theoretically occur by several mechanisms (Morales and Dujon, 2012), classified as autopolyploidization when the result is a polyploid yeast, with four allelic copies of each chromosome from one single species, or as allopolyploidization (also called amphidiploidization) when the resulting polyploidy yeast contains several copies of chromosomes from two different species. Autopolyploidization can be generated by (i) non-disjunction during one of the meiotic divisions generates diploid spores, which can subsequently conjugate with other diploid or haploid spores to form tetra- or triploid cells; (ii) a non-disjunction during mitosis in unicellular organisms also produces tetraploid cells; (iii) a rare-mating event between two diploid cells or a diploid and a haploid cells from the same species, these diploid cells become mating-competent by a gene conversion at the MAT locus. Allotetraploidization can be generated by (i) interspecific hybridization by spore-to-spore conjugation, and subsequent genome duplication by non-disjunction either during mitosis or during meiosis; (ii) interspecific rare-mating between diploid cells or between diploid and haploid cells from different species.

The analysis of complete genomes sequences from species of the Saccharomyces complex confirmed that the whole genome duplication event encompassed the entire genome and was produced by allotetraploidization due to an ancient hybridization event (Marcet-Houben and Gabaldón, 2015).

The most important consequences of the whole genome duplication event were the sudden acquisition of extra copies of each gene, with slight differences due to the chimeric origin of the duplicated genome, and the provision of new gene functions that have profoundly impacted the evolution of the Saccharomyces lineage, particularly the adaptation of these species to highly efficient fermentation performance under anaerobic conditions and the development of efficient glucose-sensing and glucoserepression pathways (Piškur and Langkjær, 2004; Wolfe, 2004). The allotetraploidization event provided the basis for the evolution of new gene functions involved in the improvement of the fermentative performance and fast growth of the ancestors of Saccharomyces yeasts, which allow to their descendant industrial yeasts to become, under the selective pressures unconsciously imposed to improve controlled fermentation processes, today's highly efficient mono- and oligosaccharide fermenters (Piškur et al., 2006).

\section{Interspecific Hybridization}

In wine Saccharomyces, another remarkable mechanism of adaptation to fermentation environments is interspecific hybridization. Reproductive isolation among Saccharomyces species is mainly postzygotic, therefore, interspecific sporeto-spore or rare-mating crosses are possible. Although these interspecific hybrids are sterile, they are viable and can reproduce asexually by budding (Naumov, 1996; Sipiczki, 2008).

A well known example of interspecific hybrids are the lager yeasts S. pastorianus (syn. S. carlsbergensis) (Kodama et al., 2005), which are partial allotetraploid hybrids between $S$. cerevisiae and S. eubayanus (Libkind et al., 2011).

Natural hybrids also appear in wine fermentation, S. uvarum $\times$ S. cerevisiae hybrids have been isolated in wines from Italy (Masneuf et al., 1998); Alsace, France (Demuyter et al., 2004; Le Jeune et al., 2007) and Tokaj, Hungary (Antunovics et al., 2005). Other type of hybrids between S. cerevisiae and S. kudriavzevii are also present in wine fermentations of European regions with Continental and Oceanic climates (González et al., 2006; Lopandic et al., 2007; Erny et al., 2012; Peris et al., 2012a). González et al. (2006) also found a S. bayanus $\times$ S. cerevisiae $\times S$. kudriavzevii hybrid isolated from Swiss wine.

By combining the phylogenetic analysis of gene sequences with all the information available on the genetic and genomic characterization of S. cerevisiae $\times S$. kudriavzevii hybrids, seven potential hybridization events have been predicted as the origin of S. kudriavzevii wine hybrids (Peris et al., 2012b). These hybrids appear to have generated by rare-mating crosses between a diploid cell of wine S. cerevisiae strains and a haploid spore or cell of European S. kudriavzevii strains, because most hybrids contain triploid chimerical genomes (Erny et al., 2012; Peris et al., 2012c).

All S. cerevisiae $\times S$. kudriavzevii natural hybrids analyzed so far predominantly maintained a S. kudriavzevii mitochondrial genome. The only exception is the commercial wine strain $\mathrm{AMH}$, which has lost $69 \%$ of the nuclear genes of S. kudriavzevii coding for proteins involved in mitochondrial functions. Contrastingly, artificial hybrids obtained under non-selective pressures, inherited their mitochondrial genome from either one or the other parental species randomly (Solieri et al., 2008; Pérez-Través et al., 2014a). This discrepancy has been associated in other hybrids to adaptation to low temperatures (Rainieri et al., 2008), the influence of respiration levels (Solieri et al., 2008; Albertin et al., 2013) or to nuclear-mitochondrial incompatibilities (Lee et al., 2008).

Interestingly, some of these $S$. cerevisiae $\times S$. kudriavzevii hybrids showed introgressions between both parental mtDNAs due to recombination in the mitochondrial COX2 gene (Peris et al., 2012a), gene that has been used to determine mitochondrial inheritance in hybrids (González et al., 2006). Similar introgressions were also found in other hybrids (PérezTravés et al., 2014b; Peris et al., 2014), and a recent study (Peris et al., 2017) demonstrated that these introgressions are very common among Saccharomyces species, which suggests extensive ancestral hybridization events during their evolutionary history.

Genome sequencing and comparative genome hybridization demonstrated that $S$. cerevisiae $\times S$. kudriavzevii hybrid strains contain aneuploidy differences and chimerical chromosomes that result from the recombination between "homeologous" chromosomes of different parental origin (Belloch et al., 2009; Borneman et al., 2012; Peris et al., 2012c) (Figure 3), promoting 


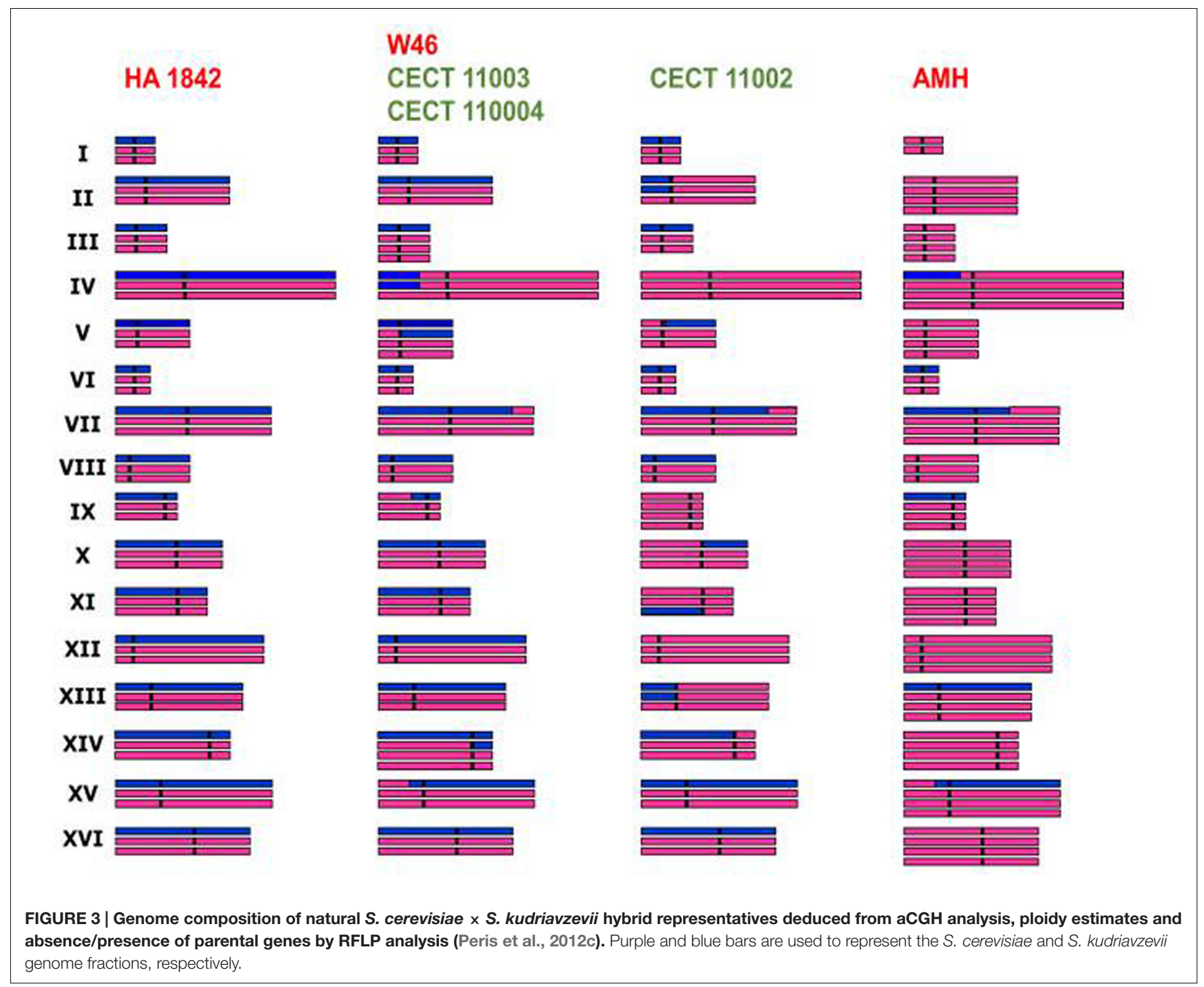

the loss of variable segments of the parental subgenomes. The evolution of hybrid genomes under stressful environmental conditions could make hybrid genomes to preserve chromosome rearrangements of selective value (Dunn et al., 2013). Therefore, interactions between both parental genomes, as well as between nuclear and mitochondrial genomes, together with the harsh environmental conditions present during fermentation, determine the final composition of hybrid genomes, which in the case of $S$. cerevisiae $\times S$. kudriavzevii hybrids is characterized by the preservation of the $S$. cerevisiae subgenome and a progressive reduction of the S. kudriavzevii fraction (Peris et al., 2012c).

The enological characterization of natural hybrid strains $S$. cerevisiae $\times S$. uvarum and $S$. cerevisiae $\times S$. kudriavzevii has demonstrated that hybrids are well-adapted to ferment at low and intermediate temperatures, produce moderate or higher glycerol levels, and less acetic acid and more aromas (higher alcohols and esters) compared to S. cerevisiae and S. kudriavzevii reference strains (González et al., 2007; Gamero et al., 2013). The advantages of these hybrids can be correlated with their genome composition (Combina et al., 2012; Gamero et al., 2014; Pérez-Torrado et al., 2015).

\section{Horizontal Gene Transfer and Introgression}

The comparative analysis of yeast genomes has shown the occurrence of genes present in a single yeast species or lineage for which the closest homologs are in bacteria (Hall et al., 2005). These genes, most of which encode metabolic enzymes, are rare in yeast genomes $(<1 \%)$, but actually appear. By way of example, Gojkovic et al. (2004) demonstrated that a horizontal gene transfer (HGT) of a dihydroorotate dehydrogenase, from Lactococcus lactis to an ancestor of yeasts Lachancea and Saccharomyces, conferred them their capability to grow under anaerobic conditions.

Another example is the reacquisition of the biotin biosynthesis pathway in Saccharomyces yeasts. This pathway was lost in an ancestor of $S$. cerevisiae, but was later rebuilt by HGT 
from bacteria and subsequent gene neofunctionalization after duplication (Hall and Dietrich, 2007).

The genome of S. cerevisiae wine yeast EC1118 (Novo et al., 2009) showed the presence of three chromosomal segments acquired through independent HGT events from other yeast species. The donors of two of these regions were later identified. Region B, which comes from Zygosaccharomyces bailii, was inserted by means of a circular DNA (Galeote et al., 2011). A recent study (Marsit et al., 2015) has demonstrated that Region $\mathrm{C}$, the largest one, derives from a recent transfer from Torulaspora microellipsoides. Marsit et al. (2015) demonstrated that the presence of FOT genes in this Region C, which facilitate the transport of the oligopeptides present in grape must, results in improved fermentation efficiency. Borneman et al. (2011) also observed a horizontally acquired cluster of five conserved ORFs that was present in most of the wine strains, encoding two potential transcription factors (one zinc-cluster, one $\mathrm{C}_{6}$ type), a cell surface flocullin, a nicotinic acid permease and a 5-oxo-Lprolinase.

For eukaryote-to-eukaryote HGT, unstable interspecific hybridization seems the most probable mechanism (Marinoni et al., 1999), although the unidirectional transfer of DNA from one nucleus to another in a newly formed hybrid prior to karyogamy has also been suggested (Morales and Dujon, 2012).

Such unstable interspecific hybridization can also explain the different events of introgression observed among Saccharomyces species (Liti et al., 2006; Dunn et al., 2012; Almeida et al., 2014). Some of these introgressed regions contain genes of adaptive value. Almeida et al. (2014) found in S. uvarum strains introgressed genome regions from $S$. eubayanus. These introgressed regions contain genes of the nitrogen metabolism, that might be advantageous in wine fermentation, in which nitrogen contents are limiting. Several S. uvarum strains isolated from New Zealand wines also contain introgressed regions from $S$. eubayanus. One of these regions comprises gene $F Z F 1$, encoding a transcription factor involved in the regulation of SSU1, the sulfite efflux pump gene. The presence of the S. eubayanus FZF1 confers a higher tolerance to sulfite to these S. uvarum strains (Zhang et al., 2015). Recently, introgressions of the SSU1 and FZF1 genes from S. paradoxus to a wild Mediterranean population of S. cerevisiae have also been described (Almeida et al., 2017), which supports the adaptive value of introgressions.

\section{METHODS TO DETECT GENETIC POLYMORPHISM}

Traditionally, yeasts have been identified and classified by morphological and physiological traits (Kurtzman et al., 2011). These methods are laborious and time-consuming, and these characteristics have been influenced by culture conditions and can provide uncertain results (Yamamoto et al., 1991). Simplified biochemical methods have also been developed based on fermentation and assimilation characteristics (Rohm, 1990). Other methods have been based on the analysis of total proteins in the cell (Van Vuuren and Meer, 1987;
Vancanneyt et al., 1991), isoenzymic patterns (Duarte et al., 1999), fatty acid analysis using gas chromatography (Cottrell et al., 1986; Tredoux et al., 1987; Moreira da Silva et al., 1994) or, more recently, the application of matrix-assisted laser desorption/ionization time of flight mass spectrometry (MALDI-TOF MS) for yeast differentiation (Blättel et al., 2013; Agustini et al., 2014), especially in the domain of medical sciences for the identification of pathogenic microorganisms (Stevenson et al., 2010; van Veen et al., 2010). However, DNA-based methods are currently the most widely used techniques for yeast differentiation. These techniques have the advantage of being independent of gene expression (Las HerasVazquez et al., 2003). Many molecular techniques have been developed to identify and characterize yeasts, such as DNADNA hybridization, electrophoretic karyotyping, restriction fragment length polymorphism (RFLP) and PCR-based methods. However, the irruption of next-generation sequencing (NGS) is revolutionizing the way for detecting genetic polymorphisms between organisms. NGS, also known as high-throughput sequencing, is the catch-all term used to describe a number of different modern sequencing technologies, which allow us to sequence DNA and RNA much more quickly and cheaply than Sanger sequencing.

Most studies into wine microbial ecology have invariably been conducted after culturing different microorganisms in distinct media. Nowadays, we witness a new era of microbiology due to the development of molecular biology techniques that allow us to identify and enumerate microorganisms using culture-independent methods. Avoiding the selective cultivation and isolation of microorganisms from natural samples is justified considering the biases related to traditional culturedependent methods (Rantsiou et al., 2005). Presence of viable, but non-culturable, microorganisms has been described in wine samples (Millet and Lonvaud-Funel, 2000; Divol and Lonvaud-Funel, 2005). These microorganisms are unable to grow in plates, which may justify the differences reported by various authors between isolated and naturally occurring species in wine samples (Cocolin and Mills, 2003; Hierro et al., 2006b).

In this section, we discuss the most recent techniques for detecting genetic polymorphisms in wine yeasts. In wine microbial diversity studies, these techniques have been used mainly for Saccharomyces strains and have been used much less for non-Saccharomyces discrimination. Depending on the degree of polymorphism provided by the various molecular markers, they are more suitable for interspecific or for intraspecific discrimination. Therefore, we divided the molecular techniques into two main groups: those that can discriminate up to the species level and those that can discriminate up to the strain level.

\section{Methods for Monitoring Yeast Species Diversity during Winemaking}

One of the most successful methods for yeast identification thanks to its rapidity and simplicity consists in the PCR amplification of ribosomal genes and the later restriction of the 
amplified fragment (PCR-RFLP). This technique is characterized by its easy execution and reproducibility. Guillamón et al. (1998) firstly adapted this technique to identify wine yeasts isolated from grape and wine fermentation processes. Later the restriction patterns of 191 yeast species were provided for the easy and reproducible identification of yeast isolated from food and fermentation processes (Esteve-Zarzoso et al., 1999; FernándezEspinar et al., 2000; de Llanos-Frutos et al., 2004). To date, this method has been applied by numerous authors to study yeast biodiversity in grapes and wines (Torija et al., 2001; Beltrán et al., 2002; Hierro et al., 2006b; Ocón et al., 2010; Tello et al., 2012; Bezerra-Bussoli et al., 2013; Díaz et al., 2013).

Other independent-culture and PCR-based methods have also been applied for studying yeast species diversity during winemaking processes. This is the case of DGGE and real-time quantitative PCR. DGGE is a semi-quantitative technique based on the sequence-specific separation of PCR-derived rRNA gene amplicons in polyacrylamide gels that contain a linearly increasing concentration of denaturant (urea and formamide), as described by Muyzer (1999). Several authors have shown that DGGE is a well-suited technique for studying yeast population dynamics during wine fermentation (Cocolin et al., 2000; Prakitchaiwattana et al., 2004; Di Maro et al., 2007; Renouf et al., 2007; Stringini et al., 2009; Pérez-Martín et al., 2014), as well as the impact of different viticultural and enological techniques in this diversity (Nisiotou and Nychas, 2007; Andorrà et al., 2008; Milanović et al., 2013). A related technique is temperature gradient gel electrophoresis (TGGE), based on a linear temperature gradient for separating DNA molecules. TGGE has also been applied to the characterization of wine yeasts (Hernán-Gómez et al., 2000; Manzano et al., 2005). However, these methods have their drawbacks: they cannot discriminate between live and dead microorganisms and minor microorganisms go undetected when they co-exist with overwhelming species populations (Andorrà et al., 2008). A modification to the DGGE method has been recently proposed by Takahashi et al. (2014) to identify low-abundant eukaryotic microorganisms. These authors modified the co-amplification at lower denaturation temperature PCR (COLD-PCR) method used to detect minor SNPs that co-exist with an overwhelming majority of wild-type (WT) sequences, as proposed by Li et al. (2008). By combining this modified COLD-PCR with DGGE (mCOLD-PCR-DGGE), these authors detected low-abundant microorganisms more efficiently, even when a specific microorganism represented an overwhelming majority of the sample. Schizosaccharomyces pombe was detected in a model sample that co-existed with 10000 times as many S. cerevisiae. When mCOLDPCR-DGGE was applied in a microbiota analysis of a fermenting white wine, Candida sp. and Cladosporium sp. were detected that were not detected by conventional PCR-DGGE.

Real-time PCR offers numerous advantages compared to other identification techniques. It is worth stressing its high specificity and sensitivity, its ability to quantify and the fact that no analysis after PCR is necessary (electrophoresis). qPCR can even be multiplexed to detect a number of organisms in one assay (Selma et al., 2009). This technique has been developed to detect and quantify total yeasts (Hierro et al., 2006a), Brettanomyces (Phister and Mills, 2003; Delaherche et al., 2004; Tofalo et al., 2012; Willenburg and Divol, 2012; Vendrame et al., 2014), Hanseniaspora (Hierro et al., 2007; Phister et al., 2007), Saccharomyces (Martorell et al., 2005b; Hierro et al., 2007; Salinas et al., 2009), and Zygosaccharomyces (Rawsthorne and Phister, 2006) in wine and other fermentation processes. The main disadvantage other than cost and personnel training lies in the method's inability to differentiate viable and non-viable microbes (Ivey and Phister, 2011). Several possible solutions have been indicated to overcome the detection of nonviable microorganisms; e.g., using RNA as a target for PCR amplification (Bleve et al., 2003; Hierro et al., 2006a) because, in theory, RNA is much more unstable than DNA, and is considered an indicator of viability; or using a fluorescent photoaffinity label which covalently couples to nucleic acids upon exposure to light, such as EMA and PMA (Andorrà et al., 2010). These dyes can only enter cells with compromised cell walls and cell membranes, and thus remove DNA from dead cells and then quantify only live microorganisms. However, this and other techniques are being replaced with the power of NGS techniques.

The determination and comparison of the nucleotide sequences of different yeast genome regions is a very useful tool for identifying and inferring phylogenetic relationships between different yeast species. The two most commonly used regions are those that correspond to domains D1 and D2 located at the $5^{\prime}$ end of gene 26S (Kurtzman and Robnett, 1998) and gene $18 \mathrm{~S}$ (James et al., 1997). The availability of these sequences in databases, especially for the D1/D2 region of gene 26S, makes this technique very useful for assigning an unknown yeast to a specific species when the percentage of homology of its sequences is over or similar to $99 \%$ (Kurtzman and Robnett, 1998). However, some authors have advocated the use of multilocus sequence analyses (MLSA) for yeast identification (Kurtzman and Robnett, 2003; Tavanti et al., 2005). These sequences were obtained by the Sanger method. However, since 2005, the NGS methods have emerged and replaced previous techniques because the sequence data generated from a single experiment are immensely more numerous. NGS tools enable the sensitive profiling of microbial communities on an unprecedented scale by the massively parallel sequencing of short (100- to 600-bp) DNA fragments amplified by PCR. The large number of sequences delivered by a single NGS run $\left(10^{4}\right.$ to $10^{8}$ reads) allows a more sensitive description of diverse microbial communities and greater multiplexing, which means a greater per-run sequencing capacity (Bokulich et al., 2014). This technology has been recently applied to study microbial diversity in grapes and wine by metagenomics approaches. Metagenomic surveillances have revealed higher diversity than other community fingerprinting methods and culture-based methods (David et al., 2014; Taylor et al., 2014). In fact, Taylor et al. (2014) suggested that culture-based methods might miss up to approximately $95 \%$ of the community in some samples. Consequently, these methods are increasingly becoming the preferred tool to evaluate grape microbial community structures. Bokulich et al. (2014) comprehensively examined the communities of both bacteria and fungi in crushed Chardonnay 
and Cabernet Sauvignon fruit in California by Illumina amplicon sequencing approaches and showed that microbiomes not only differed by region, but were also conditioned by climate, year, and cultivar. Similarly, Taylor et al. (2014) demonstrated regional distinction in fungal communities in vineyards across New Zealand. The diversity of yeasts associated with grapes and present in grape must have been shown to resemble that present on leaves (Bokulich et al., 2014; Pinto et al., 2014), and community composition to be influenced by chemical treatments, agronomic practices, and climatic conditions (Setati et al., 2012, 2015; Bokulich and Mills, 2013; David et al., 2014; Pinto et al., 2014). Setati et al. (2015) compared the mycobiome associated with South African (SA) Cabernet Sauvignon grapes in three neighboring vineyards that employed different agronomic approaches by a sequence-based metagenomic approach. The data revealed approximately 10 -fold more fungal diversity than what is typically retrieved from culture-based studies.

Similar studies are reported in the literature about monitoring yeast biodiversity in must and during alcoholic fermentation. Pinto et al. (2015) characterized the wine microbiome from six Portuguese wine appellations. The wine fermentation process revealed a stronger impact on yeast populations compared with bacterial communities, and fermentation evolution clearly caused loss of environmental microorganisms. Interestingly, a biogeographical correlation for both yeast and bacterial communities was identified between wine appellations, which suggests that each wine region contains specific embedded microbial communities that might contribute to the uniqueness of regional wines. In a similar metagenomics study conducted during the spontaneous fermentation of "Vino Santo Trentino," Stefanini et al. (2016a) also suggested the existence of a highly winery-specific "microbial-terroir" during fermentation that could contribute significantly to the final product rather than a regional "terroir." This indication was extended to humanrelated environments through the observation already made in wild environments; namely microbial populations are influenced more by microevolution in their ecological niche than by their geographical location (Morrison-Whittle and Goddard, 2015).

It is noteworthy that two recent studies compared pyrosequencing technology with some of the above-mentioned methods for studying yeast diversity during winemaking, PCR-RFLP, quantitative PCR and DGGE (David et al., 2014; Wang et al., 2015). David et al. (2014) evidenced the power of NGS technology and the drawback of the former techniques for monitoring microbial diversity. DGGE proved unsuitable for the quantification of biodiversity and its use for species detection was limited by the initial abundance of each species. The isolates identified by PCR-RFLP were not fully representative of the true population. For population dynamics, high-throughput sequencing technology yielded results that differed in some respects from those obtained by other approaches. Wang et al. (2015) reached similar conclusions; massive sequencing was more appropriate for understanding the fungal community in grape must after crushing than the other techniques used in this study. They also concluded that the "terroir" characteristics of the fungus population related more to vineyard location than to grape variety.

\section{Methods for Fingerprinting Yeast Strain Diversity during Winemaking}

Fingerprinting generally examines the whole genome of an organism by often creating a banding pattern by digesting or amplifying genome regions that can be compared between organisms (Ivey and Phister, 2011). Fingerprinting methods are characterized because they present a sufficient degree of genetic polymorphism to differentiate between strains of the same yeast species. As not all the strains of a species present the same industrial traits, availability of techniques that can discriminate at the inter- and intraspecific levels is important. As mentioned for species-differentiation techniques, new genotyping by sequencing (GBS) methods is seen as future strain genotyping. However, many studies that have compared strains still rely on some type of fingerprinting as they provide rapid and less expensive alternatives (Ivey and Phister, 2011). Although many molecular methods have been developed for yeast strain typing, most have been exclusively applied to Saccharomyces strains, although the literature offers some non Saccharomyces typing examples.

\section{Restriction Analysis of Mitochondrial DNA}

The mtDNA of $S$. cerevisiae is a small molecule of between 65 and $80 \mathrm{~kb}$, whose degree of variability can be shown by restriction. The high degree of polymorphism revealed by this technique among $S$. cerevisiae strains means that it is one of the most commonly applied techniques to characterize reference and commercial wine yeast strains (Querol et al., 1992; Guillamón et al., 1996; Fernández-Espinar et al., 2001; Esteve-Zarzoso et al., 2004; Schuller et al., 2004). This technique has been much more limited in typing strains that belong to other species, but some applications can be found in the literature to differentiate Candida spp. (Romano et al., 1996; Sabate et al., 2002), Zygosaccharomyces (Guillamón et al., 1997; Esteve-Zarzoso et al., 2003), D. bruxellensis and P. guilliermondii (Martorell et al., 2006) and Kluyveromyces (Belloch et al., 1997) strains. So although RFLP mtDNA analyses have shown narrow variability and limited usefulness for some species, it is an efficient technique for differentiating at the strain level in many other yeast species. At present, the $S$. cerevisiae $\mathrm{mtDNA}$ variability can also be analyzed by NGS methods (Wolters et al., 2015).

\section{PCR Technique-Based Methods}

The PCR technique has made available rapid methods to discriminate wine yeast strains. These methods detect the genetic polymorphism by amplifying different yeast genome regions. Amplified fragments are further separated in an agarose gel to obtain an exclusive banding pattern for each strain.

The Randomly Amplified Polymorphic DNA (RAPD-PCR) fingerprint amplifies genomic DNA with a single primer of arbitrary sequence, 9 or 10 bases in length, which hybridize with sufficient affinity to chromosomal DNA sequences at low annealing temperatures. The result is a pattern of amplified products of different molecular weights that can be characteristic of either the species or the different strains or isolates within the same species (Bruns et al., 1991; Paffetti et al., 1995). This technique has been successfully applied to differentiate wine yeast 
strains belonging to different species (Quesada and Cenis, 1995; Baleiras Couto et al., 1996; Romano et al., 1996; Tornai-Lehoczki and Dlauchy, 2000; Čadež et al., 2002; Martínez et al., 2004; Gallego et al., 2005; Martorell et al., 2006; Urso et al., 2008; Pfliegler et al., 2014).

Although yeast genomes are not very rich in repetitive sequences compared with higher eukaryotes, the recent sequencing of entire yeast genomes has revealed the presence of different repetitive regions. The use of primers based on conserved sequences of these repeated regions has proven most useful for strain differentiation by PCR. Microsatellites are short (usually less than 10-bp) sequence repeats that have been shown to exhibit a substantial level of polymorphism in a number of eukaryotic genomes (Hennequin et al., 2001). The variability found in these regions can be shown by PCR amplification using specific oligonucleotides, such as (GTG) $(\mathrm{GAG})_{5},(\mathrm{GACA})_{4}$ or M13. The ability of these oligonucleotides to reveal polymorphisms among $S$. cerevisiae strains has been demonstrated by Lieckfeldt et al. (1993) by hybridization techniques. These same authors were the first to use these sequences as primers in a PCR reaction, and proved the usefulness of this technique for characterization at the strain level. It has later been used by other authors for typing Saccharomyces (Baleiras Couto et al., 1996; Pérez et al., 2001; Howell et al., 2004; Schuller et al., 2004; Masneuf-Pomarède et al., 2007), nonSaccharomyces (Capece et al., 2003), Brettanomyces (Miot-Sertier and Lonvaud-Funel, 2007), Hanseniaspora (Caruso et al., 2002), and Zygosaccharomyces (Martorell et al., 2005a) strains.

Delta $(\delta)$ sequences are elements which measure the $0.3 \mathrm{~kb}$ that flank retrotransposons Ty1 (Cameron et al., 1979). Around $100 \delta$ copies are present in the yeast genome of $S$. cerevisiae as part of retrotransposons Ty1 or as isolated elements. The number and localization of these elements demonstrate certain intraspecific variability, which Ness et al. (1993) took advantage of to develop specific primers $\left(\delta_{1}\right.$ and $\left.\delta_{2}\right)$ that are useful to differentiate strains of $S$. cerevisiae. Later Legras and Karst (2003) optimized the technique by designing two new primers $\left(\delta_{12}\right.$ and $\delta_{21}$ ) located very near $\delta_{1}$ and $\delta_{2}$. The use of either $\delta_{12}$ and $\delta_{21}$ or $\delta_{12}$ with $\delta_{2}$ revealed a greater polymorphism as reflected by the appearance of more bands. Consequently, new primers were able to differentiate more strains, and 53 commercial strains were unequivocally differentiated (Legras and Karst, 2003). Schuller et al. (2004) confirmed this later by showing that the $\delta_{2}$ and $\delta_{12}$ combination could identify twice as many strains as the set of primers designed by Ness et al. (1993).

Approximately $5 \%$ of $S$. cerevisiae genes possess introns. These introns are spliced from pre-mRNA to form functional mature mRNAs during a process that requires the spliceosome, a large ribonucleoprotein complex. A conserved sequence is present in the intron structure for spliceosome recognition. De Barros Lopes et al. (1996) designed primers based on these conserved sequences, known as intron splice sites (ISS). The use of these primers has enabled the differentiation of a large number of commercial wine strains. ISS primers can also be used with nonSaccharomyces strains because ISS are conserved in all the yeasts that have been studied to date. Hierro et al. (2004) used these primers to identify wine strains that belong to 15 different species. This technique has also been applied to genotype B. bruxellensis strains (Oelofse et al., 2009; Vigentini et al., 2012).

Amplified Fragment Length Polymorphism (AFLP) is a technique that involves the restriction of genomic DNA, followed by binding adapters to the obtained fragments and their selective PCR amplification. The adapter sequence and restriction sites are used as target primers for PCR amplification. Amplified fragments are separated in polyacrylamide gels and different genotypes display an exclusive banding pattern (Vos et al., 1995). AFLP is a useful technique for discriminating between wine yeasts at the strain level, as shown by de Barros Lopes et al. (1999) and other authors (Azumi and Goto-Yamamoto, 2001; Boekhout et al., 2001; Lopandic et al., 2007). However, its drawback is that it is very laborious, requires automatic sequencers, highly sophisticated for the wine industry, and the results obtained are also difficult to interpret. To overcome this drawback, EsteveZarzoso et al. (2010) developed a simplified AFLP method that allowed gel electrophoresis analyses and considerably reduced equipment requirements. Another remarkable improvement was to use non-labeled primers that reduces analysis costs. This simplified method was applied to the reference strains and colonies isolated from the spontaneous fermentation of species $H$. uvarum, $H$. vinae, C. zemplinina, and S. cerevisiae. Recently, this technique has been used also to characterize genetic variability within the $H$. uvarum species (Albertin et al., 2015).

\section{AUTHOR CONTRIBUTIONS}

Both authors have contributed to the writing, revision, and final edition of this review.

\section{FUNDING}

This work has been financially supported from the Spanish Government through MINECO and FEDER funds (AGL2013-47300-C3-3-R, AGL2015-67504-C3-3-R, and PCIN2015-143grants) and from Generalitat Valenciana through PROMETEOII/2014/042 grant.

\section{ACKNOWLEDGMENT}

We acknowledge support of the publication fee by the CSIC Open Access Publication Support Initiative through its Unit of Information Resources for Research (URICI). 


\section{REFERENCES}

Aa, E., Townsend, J. P., Adams, R. I., Nielsen, K. M., and Taylor, J. W. (2006). Population structure and gene evolution in Saccharomyces cerevisiae. FEMS Yeast Res. 6, 702-715. doi: 10.1111/j.1567-1364.2006.00059.x

Agustini, B. C., Silva, L. P., Bloch, C., Bonfim, T. M. B., and Da Silva, G. A. (2014). Evaluation of MALDI-TOF mass spectrometry for identification of environmental yeasts and development of supplementary database. Appl. Microbiol. Biotechnol. 98, 5645-5654. doi: 10.1007/s00253-014-5686-7

Akao, T., Yashiro, I., Hosoyama, A., Kitagaki, H., Horikawa, H., Watanabe, D., et al. (2011). Whole-genome sequencing of sake yeast Saccharomyces cerevisiae Kyokai no. 7. DNA Res. 18, 423-434. doi: 10.1093/dnares/dsr029

Albà, M. M., Santibáñez-Koref, M. F., and Hancock, J. M. (1999). Amino acid reiterations in yeast are overrepresented in particular classes of proteins and show evidence of a slippage-like mutational process. J. Mol. Evol. 49, 789-797. doi: 10.1007/PL00006601

Albertin, W., Da Silva, T., Rigoulet, M., Salin, B., Masneuf-Pomarede, I., De Vienne, D., et al. (2013). The mitochondrial genome impacts respiration but not fermentation in interspecific Saccharomyces hybrids. PLoS ONE 8:e75121. doi: 10.1371/journal.pone.0075121

Albertin, W., Setati, M. E., Miot-Sertier, C., Mostert, T. T., ColonnaCeccaldi, B., Coulon, J., et al. (2015). Hanseniaspora uvarum from winemaking environments show spatial and temporal genetic clustering. Front. Microbiol. 6:1569. doi: 10.3389/fmicb.2015.01569

Almeida, P., Barbosa, R., Bensasson, D., Gonçalves, P., and Sampaio, J. P. (2017). Adaptive divergence in wine yeasts and their wild relatives suggests a prominent role for introgressions and rapid evolution at noncoding sites. Mol. Ecol. 26, 2167-2182. doi: 10.1111/mec.14071

Almeida, P., Barbosa, R., Zalar, P., Imanishi, Y., Shimizu, K., Turchetti, B., et al. (2015). A population genomics insight into the Mediterranean origins of wine yeast domestication. Mol. Ecol. 24, 5412-5427. doi: 10.1111/mec.13341

Almeida, P., Gonçalves, C., Teixeira, S., Libkind, D., Bontrager, M., MasneufPomarède, I., et al. (2014). A Gondwanan imprint on global diversity and domestication of wine and cider yeast Saccharomyces uvarum. Nat. Commun. 5:4044. doi: $10.1038 /$ ncomms5044

Ambrona, J., and Ramírez, M. (2007). Analysis of homothallic Saccharomyces cerevisiae strain mating during must fermentation. Appl. Environ. Microbiol. 73, 2486-2490. doi: 10.1128/AEM.02431-06

Ambrona, J., Vinagre, A., and Ramírez, M. (2005). Rapid asymmetrical evolution of Saccharomyces cerevisiae wine yeasts. Yeast 22, 1299-1306. doi: 10.1002/yea. 1331

Andorrà, I., Esteve-Zarzoso, B., Guillamón, J. M., and Mas, A. (2010). Determination of viable wine yeast using DNA binding dyes and quantitative PCR. Int. J. Food Microbiol. 144, 257-262. doi: 10.1016/j.ijfoodmicro.2010. 10.003

Andorrà, I., Landi, S., Mas, A., Guillamón, J. M., and Esteve-Zarzoso, B. (2008). Effect of oenological practices on microbial populations using cultureindependent techniques. Food Microbiol. 25, 849-856. doi: 10.1016/j.fm.2008. 05.005

Antunovics, Z., Irinyi, L., and Sipiczki, M. (2005). Combined application of methods to taxonomic identification of Saccharomyces strains in fermenting botrytized grape must. J. Appl. Microbiol. 98, 971-979. doi: 10.1111/j.1365-2672. 2005.02543.x

Argueso, J. L., Carazzolle, M. F., Mieczkowski, P. A., Duarte, F. M., Netto, O. V. C., Missawa, S. K., et al. (2009). Genome structure of a Saccharomyces cerevisiae strain widely used in bioethanol production. Genome Res. 19, 2258-2270. doi: $10.1101 /$ gr.091777.109

Arroyo-López, F. N., Pérez-Torrado, R., Querol, A., and Barrio, E. (2010). Modulation of the glycerol and ethanol syntheses in the yeast Saccharomyces kudriavzevii differs from that exhibited by S. cerevisiae and their hybrid. Food Microbiol. 27, 628-637. doi: 10.1016/j.fm.2010.02.001

Ayoub, M. J., Legras, J. L., Saliba, R., and Gaillardin, C. (2006). Application of multi locus sequence typing to the analysis of the biodiversity of indigenous Saccharomyces cerevisiae wine yeasts from Lebanon. J. Appl. Microbiol. 100, 699-711. doi: 10.1111/j.1365-2672.2006.02817.x

Azumi, M., and Goto-Yamamoto, N. (2001). AFLP analysis of type strains and laboratory and industrial strains of Saccharomyces sensu stricto and its application to phenetic clustering. Yeast 18, 1145-1154. doi: 10.1002/yea.767
Badotti, F., Vilaça, S. T., Arias, A., Rosa, C. A., and Barrio, E. (2014). Two interbreeding populations of Saccharomyces cerevisiae strains coexist in cachaça fermentations from Brazil. FEMS Yeast Res. 14, 289-301. doi: 10.1111/15671364.12108

Bakalinsky, A. T., and Snow, R. (1990). The chromosomal constitution of wine strains of Saccharomyces cerevisiae. Yeast 6, 367-382. doi: 10.1002/yea. 320060503

Baleiras Couto, M., Eijsma, B., Hofstra, H., Huisint Veld, J., and Van Der Vossen, J. (1996). Evaluation of molecular typing techniques to assign genetic diversity among Saccharomyces cerevisiae strains. Appl. Environ. Microbiol. 62, $41-46$.

Barrio, E., González, S.S., Arias, A., Belloch, C., and Querol, A. (2006). "Molecular mechanisms involved in the adaptive evolution of industrial yeasts," in Yeasts in Food and Beverages, 1st edn, eds A. Querol, and G. H. Fleet (Berlin: Springer-Verlag), 153-174.

Belloch, C., Barrio, E., Uruburu, F., García, M. D., and Querol, A. (1997). Characterization of four species of the genus Kluyveromyces by mitochondrial DNA restriction analysis. Syst. Appl. Microbiol. 20, 397-408. doi: 10.1016/ S0723-2020(97)80008-2

Belloch, C., Pérez-Torrado, R., González, S. S., Pérez-Ortín, J. E., GarcíaMartínez, J., Querol, A., et al. (2009). Chimeric genomes of natural hybrids of Saccharomyces cerevisiae and Saccharomyces kudriavzevii. Appl. Environ. Microbiol. 75, 2534-2544. doi: 10.1128/AEM.02282-08

Beltrán, G., Torija, M. J., Novo, M., Ferrer, N., Poblet, M., Guillamón, J. M., et al. (2002). Analysis of yeast populations during alcoholic fermentation: a six year follow-up study. Syst. Appl. Microbiol. 25, 287-293. doi: 10.1078/0723-202000097

Ben Ari, G., Zenvirth, D., Sherman, A., Simchen, G., Lavi, U., and Hillel, J. (2005). Application of SNPs for assessing biodiversity and phylogeny among yeast strains. Heredity 95, 493-501. doi: 10.1038/sj.hdy.6800759

Bezerra-Bussoli, C., Baffi, M. A., Gomes, E., and Da-Silva, R. (2013). Yeast diversity isolated from grape musts during spontaneous fermentation from a Brazilian winery. Curr. Microbiol. 67, 356-361. doi: 10.1007/s00284-013-0375-9

Bidenne, C., Blondin, B., Dequin, S., and Vezinhet, F. (1992). Analysis of the chromosomal DNA polymorphism of wine strains of Saccharomyces cerevisiae. Curr. Genet. 22, 1-7. doi: 10.1007/BF00351734

Blättel, V., Petri, A., Rabenstein, A., Kuever, J., and König, H. (2013). Differentiation of species of the genus Saccharomyces using biomolecular fingerprinting methods. Appl. Microbiol. Biotechnol. 97, 4597-4606. doi: $10.1007 / \mathrm{s} 00253-013-4823-\mathrm{z}$

Bleve, G., Rizzotti, L., Dellaglio, F., and Torriani, S. (2003). Development of reverse transcription (RT)-PCR and real-time RT-PCR assays for rapid detection and quantification of viable yeasts and molds contaminating yogurts and pasteurized food products. Appl. Environ. Microbiol. 69, 4116-4122. doi: 10.1128/AEM.69.7.4116-4122.2003

Boekhout, T., Theelen, B., Díaz, M. R., Fell, J. W., Hop, W. C. J., Abeln, E. C. A., et al. (2001). Hybrid genotypes in the pathogenic yeast Cryptococcus neoformans. Microbiology 147, 891-907. doi: 10.1099/00221287-147-4-891

Bokulich, N. A., and Mills, D. A. (2013). Improved selection of internal transcribed spacer-specific primers enables quantitative, ultra-high-throughput profiling of fungal communities. Appl. Environ. Microbiol. 79, 2519-2526. doi: 10.1128/ AEM.03870-12

Bokulich, N. A., Thorngate, J. H., Richardson, P. M., and Mills, D. A. (2014). Microbial biogeography of wine grapes is conditioned by cultivar, vintage, and climate. Proc. Natl. Acad. Sci. U.S.A. 111, E139-E148.

Borneman, A. R., Desany, B. A., Riches, D., Affourtit, J. P., Forgan, A. H., Pretorius, I. S., et al. (2011). Whole-genome comparison reveals novel genetic elements that characterize the genome of industrial strains of Saccharomyces cerevisiae. PLoS Genet. 7:e1001287. doi: 10.1371/journal.pgen.1001287

Borneman, A. R., Desany, B. A., Riches, D., Affourtit, J. P., Forgan, A. H., Pretorius, I. S., et al. (2012). The genome sequence of the wine yeast VIN7 reveals an allotriploid hybrid genome with Saccharomyces cerevisiae and Saccharomyces kudriavzevii origins. FEMS Yeast Res. 12, 88-96. doi: 10.1111/j.1567-1364.2011. 00773.x

Borneman, A. R., Forgan, A. H., Kolouchova, R., Fraser, J. A., and Schmidt, S. A. (2016). Whole genome comparison reveals high levels of inbreeding and strain redundancy across the spectrum of commercial wine strains of Saccharomyces cerevisiae. G3 (Bethesda) 6, 957-971. doi: 10.1534/g3.115.025692 
Bradbury, J. E., Richards, K., Niederer, H., Lee, S., Rod Dunbar, P., and Gardner, R. (2006). A homozygous diploid subset of commercial wine yeast strains. Antonie Van Leeuwenhoek 89, 27-37. doi: 10.1007/s10482-005-9006-1

Brookes, A. J. (1999). The essence of SNPs. Gene 234, 177-186. doi: 10.1016/S03781119(99)00219-X

Brown, C. A., Murray, A. W., and Verstrepen, K. J. (2010). Rapid expansion and functional divergence of subtelomeric gene families in yeasts. Curr. Biol. 20, 895-903. doi: 10.1016/j.cub.2010.04.027

Bruns, T. D., White, T. J., and Taylor, J. W. (1991). Fungal molecular systematics. Annu. Rev. Ecol. Syst. 22, 525-564.

Čadež, N., Raspor, P., Cock, A., Boekhout, T., and Smith, M. (2002). Molecular identification and genetic diversity within species of the genera Hanseniaspora and Kloeckera. FEMS Yeast Res. 1, 279-289. doi: 10.1146/annurev.es.22.110191. 002521

Cameron, J. R., Loh, E. Y., and Davis, W. (1979). Evidence for transcription of dispersed repetitive DNA families in yeast. Cell 16, 739-751. doi: 10.1016/00928674(79)90090-4

Capece, A., Salzano, G., and Romano, P. (2003). Molecular typing techniques as a tool to differentiate non-Saccharomyces wine species. Int. J. Food Microbiol. 84, 33-39. doi: 10.1016/S0168-1605(02)00392-6

Carlson, M., and Botstein, D. (1983). Organization of the SUC gene family in Saccharomyces. Mol. Cell. Biol. 3, 351-359. doi: 10.1128/MCB.3.3.351

Caruso, M., Capece, A., Salzano, G., and Romano, P. (2002). Typing of Saccharomyces cerevisiae and Kloeckera apiculata strains from Aglianico wine. Lett. Appl. Microbiol. 34, 323-328. doi: 10.1046/j.1472-765X.2002. 01090.x

Christiaens, J. F., Van Mulders, S. E., Duitama, J., Brown, C. A., Ghequire, M. G., De Meester, L., et al. (2012). Functional divergence of gene duplicates through ectopic recombination. EMBO Rep. 13, 1145-1151. doi: 10.1038/embor.2012. 157

Cocolin, L., Bisson, L. F., and Mills, D. A. (2000). Direct profiling of the yeast dynamics in wine fermentations. FEMS Microbiol. Lett. 189, 81-87. doi: 10.1111/j.1574-6968.2000.tb09210.x

Cocolin, L., and Mills, D. A. (2003). Wine yeast inhibition by sulfur dioxide: a comparison of culture-dependent and independent methods. Am. J. Enol. Vitic. 54, 125-130.

Codón, A. C., and Benítez, T. (1995). Variability of the physiological features and of the nuclear and mitochondrial genomes of baker's yeasts. Syst. Appl. Microbiol. 18, 343-352. doi: 10.1016/S0723-2020(11)80426-1

Colson, I., Delneri, D., and Oliver, S. G. (2004). Effects of reciprocal chromosomal translocations on the fitness of Saccharomyces cerevisiae. EMBO Rep. 5, 392-398. doi: 10.1038/sj.embor.7400123

Combina, M., Perez-Torrado, R., Tronchoni, J., Belloch, C., and Querol, A. (2012). Genome-wide gene expression of a natural hybrid between Saccharomyces cerevisiae and S. kudriavzevii under enological conditions. Int. J. Food Microbiol. 157, 340-345. doi: 10.1016/j.ijfoodmicro.2012.06.001

Contreras, A., Hidalgo, C., Henschke, P. A., Chambers, P. J., Curtin, C., and Varela, C. (2014). Evaluation of non-Saccharomyces yeasts for the reduction of alcohol content in wine. Appl. Environ. Microbiol. 80, 1670-1678. doi: 10.1128/ AEM.03780-13

Cottrell, M., Kock, J. L. F., Lategan, P. M., and Britz, T. J. (1986). Long-chain fatty acid composition as an aid in the classification of the genus Saccharomyces. Syst. Appl. Microbiol. 8, 166-168. doi: 10.1016/S0723-2020(86)80070-4

Dashko, S., Zhou, N., Compagno, C., Pitt, J.P.W., and Piškur, J. (2014). Why, when, and how did yeast evolve alcoholic fermentation? FEMS Yeast Res. 14, 826-832. doi: 10.1111/1567-1364.12161

David, V., Terrat, S., Herzine, K., Claisse, O., Rousseaux, S., Tourdot-Marechal, R., et al. (2014). High-throughput sequencing of amplicons for monitoring yeast biodiversity in must and during alcoholic fermentation. J. Ind. Microbiol. Biotechnol. 41, 811-821. doi: 10.1007/s10295-014-1427-2

de Barros Lopes, M., Rainieri, S., Henschke, P. A., and Langridge, P. (1999). AFLP fingerprinting for analysis of yeast genetic variation. Int. J. Syst. Bacteriol. 49, 915-924. doi: 10.1099/00207713-49-2-915

De Barros Lopes, M., Soden, A., Henschke, P. A., and Langridge, P. (1996). PCR diffferentiation of commercial yeast strains using intron splice site primers. Appl. Environ. Microbiol. 62, 4514-4520.

de Llanos-Frutos, R., Fernández-Espinar, M. T., and Querol, A. (2004). Identification of species of the genus Candida by analysis of the 5.8S rRNA gene and the two ribosomal internal transcribed spacers. Antonie van Leeuwenhoek 85, 175-185. doi: 10.1023/B:ANTO.0000020154.56649.0f

Delaherche, A., Claisse, O., and Lonvaud-Funel, A. (2004). Detection and quantification of Brettanomyces bruxellensis and 'ropy' Pediococcus damnosus strains in wine by real-time polymerase chain reaction. J. Appl. Microbiol. 97, 910-915. doi: 10.1111/j.1365-2672.2004.02334.x

Delneri, D., Colson, I., Grammenoudi, S., Roberts, I. N., Louis, E. J., and Oliver, J. L. (2003). Engineering evolution to study speciation in yeasts. Nature 422, 68-72. doi: $10.1038 /$ nature 01418

Demuyter, C., Lollier, M., Legras, J. L., and Le Jeune, C. (2004). Predominance of Saccharomyces uvarum during spontaneous alcoholic fermentation, for three consecutive years, in an Alsatian winery. J. Appl. Microbiol. 97, 1140-1148. doi: 10.1111/j.1365-2672.2004.02394.x

Di Maro, E., Ercolini, D., and Coppola, S. (2007). Yeast dynamics during spontaneous wine fermentation of the Catalanesca grape. Int. J. Food Microbiol. 117, 201-210. doi: 10.1016/j.ijfoodmicro.2007.04.007

Díaz, C., Molina, A. M., Nähring, J., and Fischer, R. (2013). Characterization and dynamic behavior of wild yeast during spontaneous wine fermentation in steel tanks and amphorae. Biomed. Res. Int. 2013, 540465. doi: 10.1155/2013/ 540465

Divol, B., and Lonvaud-Funel, A. (2005). Evidence for viable but nonculturable yeasts in botrytis-affected wine. J. Appl. Microbiol. 99, 85-93. doi: 10.1111/j. 1365-2672.2005.02578.x

Duarte, F. L., Pais, C., Spencer-Martins, I., and Leao, C. (1999). Distinctive electrophoretic isoenzyme profiles in Saccharomyces sensu stricto. Int. J. Syst. Bacteriol. 49, 1907-1913. doi: 10.1099/00207713-49-4-1907

Dujon, B., Sherman, D., Fischer, G., Durrens, P., Casaregola, S., Lafontaine, I., et al. (2004). Genome evolution in yeasts. Nature 430, 35-44. doi: 10.1038/ nature 02579

Dunham, M. J., Bradane, H., Ferea, T., Adams, J., Brown, P. O., Rosenzweig, F., et al. (2002). Characteristic genome rearrangament in experimental evolution of Saccharomyces cerevisiae. Proc. Natl. Acad. Sci. U.S.A. 99, 16144-16149. doi: 10.1073/pnas.242624799

Dunn, B., Levine, R. P., and Sherlock, G. (2005). Microarray karyotyping of commercial wine yeast strains reveals shared, as well as unique, genomic signatures. BMC Genomics 6:53. doi: 10.1186/1471-2164-6-53

Dunn, B., Paulish, T., Stanbery, A., Piotrowski, J., Koniges, G., Kroll, E., et al. (2013). Recurrent rearrangement during adaptive evolution in an interspecific yeast hybrid suggests a model for rapid introgression. PLoS Genet. 9:e1003366. doi: 10.1371/journal.pgen.1003366

Dunn, B., Richter, C., Kvitek, D. J., Pugh, T., and Sherlock, G. (2012). Analysis of the Saccharomyces cerevisiae pan-genome reveals a pool of copy number variants distributed in diverse yeast strains from differing industrial environments. Genome Res. 22, 908-924. doi: 10.1101/gr.130310.111

Engle, E. K., and Fay, J. C. (2012). Divergence of the yeast transcription factor FZF1 affects sulfite resistance. PLoS Genet. 8:e1002763. doi: 10.1371/journal. pgen. 1002763

Erny, C., Raoult, P., Alais, A., Butterlin, G., Delobel, P., Matei-Radoi, F., et al. (2012). Ecological success of a group of Saccharomyces cerevisiae/Saccharomyces kudriavzevii hybrids in the Northern European wine making environment. Appl. Environ. Microbiol. 78, 3256-3265. doi: 10.1128/AEM.06752-11

Esteve-Zarzoso, B., Belloch, C., Uruburu, F., and Querol, A. (1999). Identification of yeasts by RFLP analysis of the 5.8S rRNA gene and the two ribosomal internal transcribed spacers. Int. J. Syst. Bacteriol. 49, 329-337. doi: 10.1099/0020771349-1-329

Esteve-Zarzoso, B., Fernández-Espinar, M. T., and Querol, A. (2004). Authentication and identification of Saccharomyces cerevisiae 'flor' yeast races involved in sherry ageing. Antonie Van Leeuwenhoek 85, 151-158. doi: 10.1023/B:ANTO.0000020282.83717.bd

Esteve-Zarzoso, B., Hierro, N., Mas, A., and Guillamón, J. M. (2010). A new simplified AFLP method for wine yeast strain typing. LWT Food Sci. Technol. 43, 1480-1484. doi: 10.1016/j.lwt.2010.05.016

Esteve-Zarzoso, B., Zorman, T., Belloch, C., and Querol, A. (2003). Molecular characterisation of the species of the genus Zygosaccharomyces. Syst. Appl. Microbiol. 26, 404-411. doi: 10.1078/072320203322497437

Fay, J. C., and Benavides, J. A. (2005). Evidence for domesticated and wild populations of Saccharomyces cerevisiae. PLoS Genet. 1:e5. doi: 10.1371/journal. pgen.0010005 
Fernández-Espinar, M. T., Esteve-Zarzoso, B., Querol, A., and Barrio, E. (2000). RFLP analysis of the ribosomal internal transcribed spacers and the 5.8S rRNA gene region of the genus Saccharomyces: a fast method for species identification and the differentiation of flor yeasts. Antonie Van Leeuwenhoek 78, 87-97. doi: 10.1023/A:1002741800609

Fernández-Espinar, M. T., López, V., Ramón, D., Bartra, E., and Querol, A. (2001). Study of the authenticity of commercial wine yeast strains by molecular techniques. Int. J. Food Microbiol. 70, 1-10. doi: 10.1016/S0168-1605(01) 00502-5

Fischer, G., James, S. A., Roberts, I. N., Oliver, S. G., and Louis, E. J. (2000). Chromosomal evolution in Saccharomyces. Nature 405, 451-454. doi: 10.1038/ 35013058

Fleet, G. H., and Heard, G. M. (1993). "Yeasts-growth during fermentation," in Wine Microbiology and Biotechnology, eds G. H. Fleet and G. M. Heard (Chur: Harwood Academic Publishers), 27-55.

Force, A., Lynch, M., Pickett, F. B., Amores, A., Yan, Y. L., and Postlethwait, J. (1999). Preservation of duplicate genes by complementary, degenerative mutations. Genetics 151, 1531-1545.

Galeote, V., Bigey, F., Beyne, E., Novo, M., Legras, J. L., Casaregola, S., et al. (2011). Amplification of a Zygosaccharomyces bailii DNA segment in wine yeast genomes by extrachromosomal circular DNA formation. PLOS ONE 6:e17872. doi: 10.1371/journal.pone.0017872

Gallego, F. J., Pérez, M. A., Núñez, Y., and Hidalgo, P. (2005). Comparison of RAPDs, AFLPs and SSR markers for the genetic analysis of yeast strains of Saccharomyces cerevisiae. Food Microbiol. 22, 561-568. doi: 10.1016/j.fm.2004. 11.019

Gallone, B., Steensels, J., Prahl, T., Soriaga, L., Saels, V., Herrera-Malaver, B., et al. (2016). Domestication and divergence of Saccharomyces cerevisiae beer yeasts. Cell 166, 1397-1410.e1316. doi: 10.1016/j.cell.2016.08.020

Gamero, A., Belloch, C., Ibanez, C., and Querol, A. (2014). Molecular analysis of the genes involved in aroma synthesis in the species S. cerevisiae, S. kudriavzevii and S. bayanus var. uvarum in Winemaking Conditions. PLoS ONE 9:e97626. doi: 10.1371/journal.pone.0097626

Gamero, A., Tronchoni, J., Querol, A., and Belloch, C. (2013). Production of aroma compounds by cryotolerant Saccharomyces species and hybrids at low and moderate fermentation temperatures. J. Appl. Microbiol. 114, 1405-1414. doi: $10.1111 /$ jam. 12126

Goddard, M. R. (2008). Quantifying the complexities of Saccharomyces cerevisiae's ecosystem engineering via fermentation. Ecology 89, 2077-2082. doi: 10.1890/ 07-2060.1

Gojkovic, Z., Knecht, W., Zameitat, E., Warneboldt, J., Coutelis, J. B., Pynyaha, Y., et al. (2004). Horizontal gene transfer promoted evolution of the ability to propagate under anaerobic conditions in yeasts. Mol. Genet. Genomics 271, 387-393. doi: 10.1007/s00438-004-0995-7

González, S. S., Barrio, E., Gafner, J., and Querol, A. (2006). Natural hybrids from Saccharomyces cerevisiae, Saccharomyces bayanus and Saccharomyces kudriavzevii in wine fermentations. FEMS Yeast Res. 6, 1221-1234. doi: 10.1111/j.1567-1364.2006.00126.x

González, S. S., Gallo, L., Climent, M. D., Barrio, E., and Querol, A. (2007). Enological characterization of natural hybrids from Saccharomyces cerevisiae and S. kudriavzevii. Int. J. Food Microbiol. 116, 11-18. doi: 10.1016/j. ijfoodmicro.2006.10.047

González-Techera, A., Jubany, S., Carrau, F. M., and Gaggero, C. (2001). Differentiation of industrial wine yeast strains using microsatellite markers. Lett. Appl. Microbiol. 33, 71-75. doi: 10.1046/j.1472-765X.2001. 00946.x

Guijo, S., Mauricio, J. C., Salmón, J. M., and Ortega, J. M. (1997). Determination of the relative ploidy in different Saccharomyces cerevisiae strains used for fermentation and 'flor' film ageing of dry sherry-type wines. Yeast 13, 101-117. doi: 10.1002/(SICI) 1097-0061(199702)13:2<101::AID-YEA66>3.0.CO;2-H

Guillamón, J. M., Barrio, E., and Querol, A. (1996). Characterization of wine yeast strains of the Saccharomyces genus on the basis of molecular markers: relationships between genetic distance and geographic or ecological origin. Syst. Appl. Microbiol. 19, 122-132. doi: 10.1016/S0723-2020(96)80019-1

Guillamón, J. M., Sabaté, J., Barrio, E., Cano, J., and Querol, A. (1998). Rapid identification of wine yeast species based on RFLP analysis of the ribosomal internal transcribed spacer (ITS) region. Arch. Microbiol. 169, 387-392. doi: $10.1007 / \mathrm{s} 002030050587$
Guillamón, J. M., Sánchez, I., and Huerta, T. (1997). Rapid characterization of wild and collection strains of the genus Zygosaccharomyces according to mitochondrial DNA patterns. FEMS Microbiol. Lett. 147, 267-272. doi: 10. 1111/j.1574-6968.1997.tb10252.x

Guillaume, C., Delobel, P., Sablayrolles, J. M., and Blondin, B. (2007). Molecular basis of fructose utilization by the wine yeast Saccharomyces cerevisiae: a mutated HXT3 allele enhances fructose fermentation. Appl. Environ. Microbiol. 73, 2432-2439. doi: 10.1128/AEM.02269-06

Hall, C., Brachat, S., and Dietrich, F. S. (2005). Contribution of horizontal gene transfer to the evolution of Saccharomyces cerevisiae. Eukaryot. Cell 4, 1102-1115. doi: 10.1128/EC.4.6.1102-1115.2005

Hall, C., and Dietrich, F. S. (2007). The reacquisition of biotin prototrophy in Saccharomyces cerevisiae Involved horizontal gene transfer, Gene duplication and gene clustering. Genetics 177, 2293-2307. doi: 10.1534/genetics.107. 074963

Hennequin, C., Thierry, A., Richard, G. F., Lecointre, G., Nguyen, H. V., Gaillardin, C., et al. (2001). Microsatellite typing as a new tool for identification of Saccharomyces cerevisiae strains. J. Clin. Microbiol. 39, 551-559. doi: 10.1128/ JCM.39.2.551-559.2001

Hernán-Gómez, S., Espinosa, J. C., and Úbeda, J. F. (2000). Characterization of wine yeasts by temperature gradient gel electrophoresis (TGGE). FEMS Microbiol. Lett. 193, 45-50. doi: 10.1016/S0378-1097(00)00452-3

Hierro, N., Esteve-Zarzoso, B., González, A., Mas, A., and Guillamón, J. M. (2006a). Real-time quantitative PCR (qPCR) and reverse transcription-qPCR for detection and enumeration of total yeasts in wine. Appl. Environ. Microbiol. 72, 7148-7155. doi: 10.1128/AEM.00388-06

Hierro, N., Esteve-Zarzoso, B., Mas, A., and Guillamón, J. M. (2007). Monitoring of Saccharomyces and Hanseniaspora populations during alcoholic fermentation by real-time quantitative PCR. FEMS Yeast Res. 7, 1340-1349. doi: 10.1111/j. 1567-1364.2007.00304.x

Hierro, N., González, A., Mas, A., and Guillamón, J. M. (2004). New PCR-based methods for yeast identification. J. Appl. Microbiol. 97, 792-801. doi: 10.1111/j. 1365-2672.2004.02369.x

Hierro, N., González, A., Mas, A., and Guillamón, J. M. (2006b). Diversity and evolution of non-Saccharomyces yeast populations during wine fermentation: effect of grape ripeness and cold maceration. FEMS Yeast Res. 6, 102-111. doi: 10.1111/j.1567-1364.2005.00014.x

Hittinger, C. T., and Carroll, S. B. (2007). Gene duplication and the adaptive evolution of a classic genetic switch. Nature 449, 677-681. doi: 10.1038/ nature 06151

Howell, K. S., Bartowsky, E. J., Fleet, G. H., and Henschke, P. A. (2004). Microsatellite PCR profiling of Saccharomyces cerevisiae strains during wine fermentation. Lett. Appl. Microbiol. 38, 315-320. doi: 10.1111/j.1472-765X. 2004.01486.x

Hughes, T. R., Roberts, C. J., Dai, H. Y., Jones, A. R., Meyer, M. R., Slade, D., et al. (2000). Widespread aneuploidy revealed by DNA microarray expression profiling. Nat. Genet. 25, 333-337. doi: 10.1038/77116

Hyma, K. E., and Fay, J. C. (2013). Mixing of vineyard and oak-tree ecotypes of Saccharomyces cerevisiae in North American vineyards. Mol. Ecol. 22, 2917-2930. doi: 10.1111/mec.12155

Infante, J. J., Dombek, K. M., Rebordinos, L., Cantoral, J. M., and Young, E. T. (2003). Genome-wide amplifications caused by chromosomal rearrangements play a major role in the adaptive evolution of natural yeast. Genetics 165, $1745-1759$.

Ivey, M. L., and Phister, T. G. (2011). Detection and identification of microorganisms in wine: a review of molecular techniques. J. Ind. Microbiol. Biotechnol. 38, 1619-1634. doi: 10.1007/s10295-011-1020-x

James, S. A., Chi, J. P., Roberts, I. N., and Collins, M. D. (1997). A phylogenetic analysis of the genus Saccharomyces based on 18S rRNA gene sequences: description of Saccharomyces kunashirensis sp nov and Saccharomyces martiniae sp nov. Int. J. Syst. Bacteriol. 47, 453-460. doi: 10.1099/0020771347-2-453

Jolly, N. P., Varela, C., and Pretorius, I. S. (2014). Not your ordinary yeast: nonSaccharomyces yeasts in wine production uncovered. FEMS Yeast Res. 14, 215-237. doi: 10.1111/1567-1364.12111

Jones, G. V., White, M. A., Cooper, O. R., and Storchmann, K. (2005). Climate change and global wine quality. Clim. Change 73, 319-343. doi: 10.1007/s10584005-4704-2 
Katz Ezov, T., Boger-Nagjar, E., Frenkel, Z. E., Katsperovski, I., Kemeny, S., Nevo, E., et al. (2006). Molecular-genetic biodiversity in natural population of yeast S. cerevisiae from "Evolution Canyon": Microsatellite polymorphism, ploidy, and controversial sexual status. Genetics 174, 1455-1468. doi: 10.1534/ genetics.106.062745

Kellis, M., Patterson, N., Endrizzi, M., Birren, B. W., and Lander, E. S. (2003). Sequencing and comparison of yeast species to identify genes and regulatory elements. Nature 423, 241-254. doi: 10.1038/nature01644

Kodama, Y., Kielland-Brandt, M.C., and Hansen, J. (2005). "Lager brewing yeast," in Comparative Genomics: Using Fungi as Models, 1st Edn, eds P. Sunnerhagen and J. Piškur (Berlin: Springer-Verlag), 145-164.

Koszul, R., Dujon, B., and Fischer, G. (2006). Stability of large segmental duplications in the yeast genome. Genetics 172, 2211-2222. doi: 10.1534/ genetics.105.048058

Koufopanou, V., Hughes, J., Bell, G., and Burt, A. (2006). The spatial scale of genetic differentiation in a model organism: the wild yeast Saccharomyces paradoxus. Philos. Trans. R. Soc. Lond. Ser. B Biol. Sci. 361, 1941-1946. doi: 10.1098/rstb.2006.1922

Kuehne, H. A., Murphy, H. A., Francis, C. A., and Sniegowski, P. D. (2007). Allopatric divergence, secondary contact, and genetic isolation in wild yeast populations. Curr. Biol. 17, 407-411. doi: 10.1016/j.cub.2006.12.047

Kurtzman, C. P., Fell, J. W., and Boekhout, T. (2011). The Yeasts, A Taxonomic Study. London: Elsevier.

Kurtzman, C. P., and Robnett, C. J. (1998). Identification and phylogeny of ascomycetous yeasts from analysis of nuclear large subunit (26S) ribosomal DNA partial sequences. Antonie Van Leeuwenhoek 73, 331-371. doi: 10.1023/A: 1001761008817

Kurtzman, C. P., and Robnett, C. J. (2003). Phylogenetic relationships among yeasts of the 'Saccharomyces complex' determined from multigene sequence analyses. FEMS Yeast Res. 3, 417-432. doi: 10.1016/S1567-1356(03) 00012-6

Las Heras-Vazquez, F. J., Mingorance-Cazoeerla, L., Clemente-Jimenez, J. M., and Rodriguez-Vico, F. (2003). Identification of yeasts species from orange fruit and juice by RFLP and sequence analysis of the 5.8S rRNA gene and the two internal transcribed spacers. FEMS Yeast Res. 3, 3-9. doi: 10.1111/j.1567-1364. 2003.tb00132.x

Le Jeune, C., Lollier, M., Demuyter, C., Erny, C., Legras, J. L., Aigle, M., et al. (2007). Characterization of natural hybrids of Saccharomyces cerevisiae and Saccharomyces bayanus var. uvarum. FEMS Yeast Res. 7, 540-549. doi: 10.1111/ j.1567-1364.2007.00207.x

Lee, H. Y., Chou, J. Y., Cheong, L., Chang, N. H., Yang, S. Y., and Leu, J. Y. (2008). Incompatibility of nuclear and mitochondrial genomes causes hybrid sterility between two yeast species. Cell 135, 1065-1073. doi: 10.1016/j.cell.2008. 10.047

Legras, J. L., and Karst, F. (2003). Optimisation of interdelta analysis for Saccharomyces cerevisiae strain characterisation. FEMS Microbiol. Lett. 221, 249-255. doi: 10.1016/S0378-1097(03)00205-2

Legras, J. L., Merdinoglu, D., Cornuet, J. M., and Karst, F. (2007). Bread, beer and wine: Saccharomyces cerevisiae diversity reflects human history. Mol. Ecol. 16, 2091-2102. doi: 10.1111/j.1365-294X.2007.03266.x

Legras, J. L., Ruh, O., Merdinoglu, D., and Karst, F. (2005). Selection of hypervariable microsatellite loci for the characterization of Saccharomyces cerevisiae strains. Int. J. Food Microbiol. 102, 73-83. doi: 10.1016/j.ijfoodmicro. 2004.12.007

Li, J., Wang, L., Mamon, H., Kulke, M. H., Berbeco, R., and Makrigiorgos, G. M. (2008). Replacing PCR with COLD-PCR enriches variant DNA sequences and redefines the sensitivity of genetic testing. Nat. Med. 14, 579-584. doi: 10.1038/ nm1708

Libkind, D., Hittinger, C. T., Valério, E., Gonçalves, C., Dover, J., Johnston, M., et al. (2011). Microbe domestication and the identification of the wild genetic stock of lager-brewing yeast. Proc. Natl. Acad. Sci. U.S.A. 108, 14539-14544. doi: $10.1073 /$ pnas.1105430108

Lieckfeldt, E., Meyer, W., and Börner, T. (1993). Rapid identification and differentiation of yeasts by DNA and PCR fingerprinting. J. Basic Microbiol. 33, 413-425. doi: 10.1002/jobm.3620330609

Liti, G., Barton, D. B. H., and Louis, E. J. (2006). Sequence diversity, reproductive isolation and species concepts in Saccharomyces. Genetics 174, 839-850. doi: 10.1534/genetics.106.062166
Liti, G., Carter, D. M., Moses, A. M., Warringer, J., Parts, L., James, S. A., et al. (2009). Population genomics of domestic and wild yeasts. Nature 458, 337-341. doi: $10.1038 /$ nature 07743

Liti, G., and Louis, E. J. (2005). Yeast evolution and comparative genomics. Annu. Rev. Microbiol. 59, 135-153. doi: 10.1146/annurev.micro.59.030804.121400

Lopandic, K., Gangl, H., Wallner, E., Tscheik, G., Leitner, G., Querol, A., et al. (2007). Genetically different wine yeasts isolated from Austrian vine-growing regions influence wine aroma differently and contain putative hybrids between Saccharomyces cerevisiae and Saccharomyces kudriavzevii. FEMS Yeast Res. 7, 953-965. doi: 10.1111/j.1567-1364.2007.00240.x

Magwene, P. M., Kayıkçı, Ö., Granek, J. A., Reininga, J. M., Scholl, Z., and Murray, D. (2011). Outcrossing, mitotic recombination, and lifehistory trade-offs shape genome evolution in Saccharomyces cerevisiae. Proc. Natl. Acad. Sci. U.S.A. 108, 1987-1992. doi: 10.1073/pnas.10125 44108

Malpertuy, A., Dujon, B., and Richard, G. F. (2003). Analysis of microsatellites in 13 hemiascomycetous yeast species: mechanisms involved in genome dynamics. J. Mol. Evol. 56, 730-741. doi: 10.1007/s00239-002-2447-5

Manzano, M., Cocolin, L., Iacumin, L., Cantoni, C., and Comi, G. (2005). A PCR-TGGE (Temperature Gradient Gel Electrophoresis) technique to assess differentiation among enological Saccharomyces cerevisiae strains. Int. J. Food Microbiol. 101, 333-339. doi: 10.1016/j.ijfoodmicro.2004. 10.049

Marcet-Houben, M., and Gabaldón, T. (2015). Beyond the whole-genome duplication: phylogenetic evidence for an ancient interspecies hybridization in the baker's yeast lineage. PLoS Biol. 13:e1002220. doi: 10.1371/journal.pbio. 1002220

Marinoni, G., Manuel, M., Petersen, R. F., Hvidtfeldt, J., Sulo, P., and Piskur, J. (1999). Horizontal transfer of genetic material among Saccharomyces yeasts. J. Bacteriol. 181, 6488-6496.

Marsit, S., and Dequin, S. (2015). Diversity and adaptive evolution of Saccharomyces wine yeast: a review. FEMS Yeast Res. 15:fov67. doi: 10.1093/ femsyr/fov067

Marsit, S., Mena, A., Bigey, F., Sauvage, F.-X., Couloux, A., Guy, J., et al. (2015). Evolutionary advantage conferred by an Eukaryote-to-Eukaryote gene transfer event in wine yeasts. Mol. Biol. Evol. 32, 1695-1707. doi: 10.1093/molbev/ msv057

Martínez, C., Gac, S., Lavin, A., and Ganga, M. A. (2004). Genomic characterization of Saccharomyces cerevisiae strains isolated from wine-producing areas in South America. J. Appl. Microbiol. 96, 1161-1168. doi: 10.1111/j.1365-2672.2004. 02255.x

Martínez, P., Codón, A. C., Pérez, L., and Benítez, T. (1995). Physiological and molecular characterization of flor yeasts: polymorphism of flor yeast populations. Yeast 11, 1399-1411. doi: 10.1002/yea.320111408

Martorell, P., Barata, A., Malfeito-Ferreira, M., Fernández-Espinar, M. T., Loureiro, V., and Querol, A. (2006). Molecular typing of the yeast species Dekkera bruxellensis and Pichia guilliermondii recovered from wine related sources. Int. J. Food Microbiol. 106, 79-84. doi: 10.1016/j.ijfoodmicro.2005. 05.014

Martorell, P., Fernández-Espinar, M. T., and Querol, A. (2005a). Molecular monitoring of spoilage yeasts during the production of candied fruit nougats to determine food contamination sources. Int. J. Food Microbiol. 101, 293-302. doi: 10.1016/j.ijfoodmicro.2004.11.014

Martorell, P., Querol, A., and Fernández-Espinar, M. T. (2005b). Rapid identification and enumeration of Saccharomyces cerevisiae cells in wine by realtime PCR. Appl. Environ. Microbiol. 71, 6823-6830. doi: 10.1128/AEM.71.11. 6823-6830.2005

Marullo, P., Aigle, M., Bely, M., Masneuf-Pomarède, I., Durrens, P., Dubourdieu, D., et al. (2007). Single QTL mapping and nucleotide-level resolution of a physiologic trait in wine Saccharomyces cerevisiae strains. FEMS Yeast Res. 7, 941-952. doi: 10.1111/j.1567-1364.2007.00252.x

Masneuf, I., Hansen, J., Groth, C., Piškur, J., and Dubourdieu, D. (1998). New hybrids between Saccharomyces sensu stricto yeast species found among wine and cider production strains. Appl. Environ. Microbiol. 64, 3887-3892.

Masneuf-Pomarède, I., Le Jeune, C., Durrens, P., Lollier, M., Aigle, M., and Dubourdieu, D. (2007). Molecular typing of wine yeast strains Saccharomyces bayanus var. uvarum using microsatellite markers. Syst. Appl. Microbiol. 30, 75-82. doi: 10.1016/j.syapm.2006.02.006 
McGovern, P. E., Hartung, U., Badler, V. R., Glusker, D. L., and Exner, L. J. (1997). The beginnings of winemaking and viniculture in the ancient Near East and Egypt. Expedition 39, 3-21.

Medina, K., Boido, E., Fariña, L., Gioia, O., Gomez, M. E., Barquet, M., et al. (2013). Increased flavour diversity of Chardonnay wines by spontaneous fermentation and co-fermentation with Hanseniaspora vineae. Food Chem. 141, 2513-2521. doi: 10.1016/j.foodchem.2013.04.056

Milanović, V., Comitini, F., and Ciani, M. (2013). Grape berry yeast communities: influence of fungicide treatments. Int. J. Food Microbiol. 161, 240-246. doi: 10.1016/j.ijfoodmicro.2012.12.019

Millet, V., and Lonvaud-Funel, A. (2000). The viable but non-culturable state of wine micro-organisms during storage. Lett. Appl. Microbiol. 30, 136-141. doi: 10.1046/j.1472-765x.2000.00684.x

Miot-Sertier, C., and Lonvaud-Funel, A. (2007). Development of a molecular method for the typing of Brettanomyces bruxellensis (Dekkera bruxellensis) at the strain level. J. Appl. Microbiol. 102, 555-562. doi: 10.1111/j.1365-2672.2006. 03069.x

Morales, L., and Dujon, B. (2012). Evolutionary role of interspecies hybridization and genetic exchanges in yeasts. Microbiol. Mol. Biol. Rev. 76, 721-739. doi: 10.1128/MMBR.00022-12

Morales, P., Rojas, V., Quirós, M., and Gonzalez, R. (2015). The impact of oxygen on the final alcohol content of wine fermented by a mixed starter culture. Appl. Microbiol. Biotechnol. 99, 3993-4003. doi: 10.1007/s00253-0146321-3

Moreira da Silva, M., Malfeito-Ferreira, M., Loureiro, V., and Aubyn, A. S. (1994). Long chain fatty acid composition as criterion for yeast distinction in the brewing industry. J. Inst. Brew. 100, 17-22. doi: 10.1002/j.2050-0416.1994. tb00805.x

Morrison-Whittle, P., and Goddard, M. R. (2015). Quantifying the relative roles of selective and neutral processes in defining eukaryotic microbial communities. ISME J. 9, 2003-2011. doi: 10.1038/ismej.2015.18

Mortimer, R. K. (2000). Evolution and variation of the yeast (Saccharomyces) genome. Genome Res. 10, 403-409. doi: 10.1101/gr.10.4.403

Muyzer, G. (1999). DGGE/TGGE a method for identifying genes from natural ecosystems. Curr. Opin. Microbiol. 2, 317-322. doi: 10.1016/S1369-5274(99) 80055- 1

Nadal, D., Carro, D., Fernández-Larrea, J., and Pina, B. (1999). Analysis and dynamics of the chromosomal complements of wild sparkling-wine yeast strains. Appl. Environ. Microbiol. 65, 1688-1695.

Naumov, G. I. (1996). Genetic identification of biological species in the Saccharomyces sensu stricto complex. J. Ind. Microbiol. 17, 295-302. doi: 10.1007/BF01574704

Ness, F., and Aigle, M. (1995). RTM1: a member of a new family of telomeric repeated genes in yeast. Genetics 140, 945-956.

Ness, F., Lavallée, F., Dubourdieu, D., Aigle, M., and Dulau, L. (1993). Identification of yeast strains using the polymerase chain reaction. J. Sci. Food Agric. 62, 89-94. doi: $10.1002 /$ jsfa.2740620113

Nisiotou, A. A., and Nychas, G. J. (2007). Yeast populations residing on healthy or botrytis-infected grapes from a vineyard in Attica, Greece. Appl. Environ. Microbiol. 73, 2765-2768. doi: 10.1128/AEM.01864-06

Novo, M., Bigey, F., Beyne, E., Galeote, V., Gavory, F., Mallet, S., et al. (2009). Eukaryote-to-eukaryote gene transfer events revealed by the genome sequence of the wine yeast Saccharomyces cerevisiae EC1118. Proc. Natl. Acad. Sci. U.S.A. 106, 16333-16338. doi: 10.1073/pnas.0904673106

Ocón, E., Gutiérrez, A. R., Garijo, P., López, R., and Santamaría, P. (2010). Presence of non-Saccharomyces yeasts in cellar equipment and grape juice during harvest time. Food Microbiol. 27, 1023-1027. doi: 10.1016/j.fm.2010.06.012

Oelofse, A., Lonvaud-Funel, A., and Du Toit, M. (2009). Molecular identification of Brettanomyces bruxellensis strains isolated from red wines and volatile phenol production. Food Microbiol. 26, 377-385. doi: 10.1016/j.fm.2008.10.011

Oliveira, B. M., Barrio, E., Querol, A., and Pérez-Torrado, R. (2014). Enhanced enzymatic activity of glycerol-3-phosphate dehydrogenase from the cryophilic Saccharomyces kudriavzevii. PLOS ONE 9:e87290. doi: 10.1371/journal.pone. 0087290

Paffetti, D., Barberio, C., Casalone, E., Cavalieri, D., Fani, R., Fia, G., et al. (1995). DNA fingerprinting by random amplified polymorphic DNA and restriction fragment length polymorphism is useful for yeast typing. Res. Microbiol. 146, 587-594. doi: 10.1016/0923-2508(96)80565-1
Pâques, F., and Haber, J. E. (1999). Multiple pathways of recombination induced by double-strand breaks in Saccharomyces cerevisiae. Microbiol. Mol. Biol. Rev. 63, 349-404.

Pérez, M. A., Gallego, F. J., Martínez, I., and Hidalgo, P. (2001). Detection, distribution and selection of microsatellites (SSRs) in the genome of the yeast Saccharomyces cerevisiae as molecular markers. Lett. Appl. Microbiol. 33, 461-466. doi: 10.1046/j.1472-765X.2001.01032.x

Pérez-Martín, F., Seseña, S., Fernández-González, M., Arévalo, M., and Palop, M. L. (2014). Microbial communities in air and wine of a winery at two consecutive vintages. Int. J. Food Microbiol. 190, 44-53. doi: 10.1016/j.ijfoodmicro.2014.08. 020

Pérez-Ortín, J. E., Querol, A., Puig, S., and Barrio, E. (2002). Molecular characterization of a chromosomal rearrangement involved in the adaptive evolution of yeast strains. Genome Res. 12, 1533-1539. doi: 10.1101/gr.436602

Pérez-Torrado, R., González, S. S., Combina, M., Barrio, E., and Querol, A. (2015). Molecular and enological characterization of a natural Saccharomyces uvarum and Saccharomyces cerevisiae hybrid. Int. J. Food Microbiol. 204, 101-110. doi: 10.1016/j.ijfoodmicro.2015.03.012

Pérez-Través, L., Lopes, C. A., Barrio, E., and Querol, A. (2014a). Stabilization process in Saccharomyces intra- and interspecific hybrids in fermentative conditions. Int. Microbiol. 17, 213-224.

Pérez-Través, L., Lopes, C. A., Querol, A., and Barrio, E. (2014b). On the complexity of the Saccharomyces bayanus taxon: hybridization and potential hybrid speciation. PLOS ONE 9:e93729. doi: 10.1371/journal.pone. 0093729

Peris, D., Arias, A., Orliæ, S., Belloch, C., Pérez-Través, L., Querol, A., et al. (2017). Mitochondrial introgression suggests extensive ancestral hybridization events among Saccharomyces species. Mol. Phylogenet. Evol. 108, 49-60. doi: 10.1016/ j.ympev.2017.02.008

Peris, D., Belloch, C., Lopandic, K., Álvarez-Pérez, J.M., Querol, A., and Barrio, E. (2012a). The molecular characterization of new types of Saccharomyces cerevisiae x $S$. kudriavzevii hybrid yeasts unveils a high genetic diversity. Yeast 29, 81-91. doi: 10.1002/yea.2891

Peris, D., Lopes, C.A., Arias, A., and Barrio, E. (2012b). Reconstruction of the evolutionary history of Saccharomyces cerevisiae $\mathrm{x} S$. kudriavzevii hybrids based on multilocus sequence analysis. PLoS ONE 7:e45527. doi: 10.1371/journal. pone.0045527

Peris, D., Lopes, C. A., Belloch, C., Querol, A., and Barrio, E. (2012c). Comparative genomics among Saccharomyces cerevisiae $\mathrm{x}$ Saccharomyces kudriavzevii natural hybrid strains isolated from wine and beer reveals different origins. BMC Genomics 13:407. doi: 10.1186/1471-2164-13-407

Peris, D., Perez-Traves, L., Belloch, C., and Querol, A. (2016). Enological characterization of Spanish Saccharomyces kudriavzevii strains, one of the closest relatives to parental strains of winemaking and brewing Saccharomyces cerevisiae x S-kudriavzevii hybrids. Food Microbiol. 53, 31-40. doi: 10.1016/j.fm. 2015.07.010

Peris, D., Sylvester, K., Libkind, D., Gonçalves, P., Sampaio, J. P., Alexander, W. G., et al. (2014). Population structure and reticulate evolution of Saccharomyces eubayanus and its lager-brewing hybrids. Mol. Ecol. 23, 2031-2045. doi: $10.1111 /$ mec. 12702

Pfliegler, W. P., Horváth, E., Kállai, Z., and Sipiczki, M. (2014). Diversity of Candida zemplinina isolates inferred from RAPD, micro/minisatellite and physiological analysis. Microbiol. Res. 169, 402-410. doi: 10.1016/j.micres.2013.09.006

Phister, T. G., and Mills, D. A. (2003). Real-time PCR assay for detection and enumeration of Dekkera bruxellensis in wine. Appl. Environ. Microbiol. 69, 7430-7434. doi: 10.1128/AEM.69.12.7430-7434.2003

Phister, T.G., Rawsthorne, H., Joseph, C.M.L., and Mills, D.A. (2007). Real-time PCR assay for detection and enumeration of Hanseniaspora species from wine and juice. Am. J. Enol. Viticult. 58, 229-233.

Pinto, C., Pinho, D., Cardoso, R., Custodio, V., Fernandes, J., Sousa, S., et al. (2015). Wine fermentation microbiome: a landscape from different Portuguese wine appellations. Front. Microbiol. 6:905. doi: 10.3389/fmicb.2015.00905

Pinto, C., Pinho, D., Sousa, S., Pinheiro, M., Egas, C., and Gomes, A. C. (2014). Unravelling the diversity of grapevine microbiome. PLOS ONE 9:e85622. doi: 10.1371/journal.pone.0085622

Piškur, J., and Langkjær, R. B. (2004). Yeast genome sequencing: the power of comparative genomics. Mol. Microbiol. 53, 381-389. doi: 10.1111/j.1365-2958. 2004.04182.x 
Piškur, J., Rozpedowska, E., Polakova, S., Merico, A., and Compagno, C. (2006). How did Saccharomyces evolve to become a good brewer? Trends Genet. 22, 183-186.

Prakitchaiwattana, C. J., Fleet, G. H., and Heard, G. M. (2004). Application and evaluation of denaturing gradient gel electrophoresis to analyse the yeast ecology of wine grapes. FEMS Yeast Res. 4, 865-877. doi: 10.1016/j.femsyr.2004. 05.004

Pretorius, I. S. (2000). Tailoring wine yeast for the new millennium: novel approaches to the ancient art of winemaking. Yeast 16, 675-729. doi: 10.1002/ 1097-0061(20000615)16:8<675::AID-YEA585>3.0.CO;2-B

Puig, S., Querol, A., Barrio, E., and Pérez-Ortín, J. E. (2000). Mitotic recombination and genetic changes in Saccharomyces cerevisiae during wine fermentation. Appl. Environ. Microbiol. 66, 2057-2061. doi: 10.1128/AEM.66.5.2057-2061. 2000

Pulvirenti, A., Zambonelli, C., Todaro, A., and Giudici, P. (2002). Interspecific hybridisation by digestive tract of invertebrates as a source of environmental biodiversity within the Saccharomyces cerevisiae. Ann. Microbiol. 52, 245-255.

Querol, A., Barrio, E., and Ramón, D. (1992). A comparative study of different methods of yeast-strain characterization. Syst. Appl. Microbiol. 15, 439-446. doi: 10.1016/S0723-2020(11)80219-5

Quesada, M. P., and Cenis, J. L. (1995). Use of random amplified polymorphic DNA (RAPD-PCR) in the characterization of wine yeasts. Am. J. Enol. Vitic. 46, 204-208.

Rachidi, N., Barre, P., and Blondin, B. (1999). Multiple Ty-mediated chromosomal translocation lead to karyotype changes in a wine strain of Saccharomyces cerevisiae. Mol. Gen. Genet. 261, 841-850. doi: 10.1007/s0043800 50028

Rainieri, S., Kodama, Y., Nakao, Y., Pulvirenti, A., and Giudici, P. (2008). The inheritance of mitochondrial DNA in lager brewing strains. FEMS Yeast Res. 8, 586-596. doi: 10.1111/j.1567-1364.2008.00363.x

Ramírez, M., Vinagre, A., Ambrona, J., Molina, F., Maqueda, M., and Rebollo, J. E. (2004). Genetic instability of heterozygous, hybrid, natural wine yeasts. Appl. Environ. Microbiol. 70, 4686-4691. doi: 10.1128/AEM.70.8.4686-4691.2004

Rantsiou, K., Urso, R., Iacumin, L., Cantoni, C., Cattaneo, P., Comi, G., et al. (2005). Culture-dependent and -independent methods to investigate the microbial ecology of Italian fermented sausages. Appl. Environ. Microbiol. 71, 1977-1986. doi: 10.1128/AEM.71.4.1977-1986.2005

Rawsthorne, H., and Phister, T. G. (2006). A real-time PCR assay for the enumeration and detection of Zygosaccharomyces bailii from wine and fruit juices. Int. J. Food Microbiol. 112, 1-7. doi: 10.1016/j.ijfoodmicro.2006. 05.003

Renault, P., Miot-Sertier, C., Marullo, P., Hernández-Orte, P., Lagarrigue, L., Lonvaud-Funel, A., et al. (2009). Genetic characterization and phenotypic variability in Torulaspora delbrueckii species: Potential applications in the wine industry. Int. J. Food Microbiol. 134, 201-210. doi: 10.1016/j.ijfoodmicro.2009. 06.008

Renouf, V., Claisse, O., and Lonvaud-Funel, A. (2007). Inventory and monitoring of wine microbial consortia. Appl. Microbiol. Biotechnol. 75, 149-164. doi: 10.1007/s00253-006-0798-3

Richard, G. F., and Dujon, B. (1997). Trinucleotide repeats in yeast. Res. Microbiol. 148, 731-744. doi: 10.1016/S0923-2508(97)82449-7

Rohm, H. (1990). Evaluation and reliability of a simplified method for identification of food-borne yeasts. Appl. Environ. Microbiol. 56, 1290-1295.

Romano, A., Casaregola, S., Torre, P., and Gaillardin, C. (1996). Use of rapid and mitochondrial DNA RFLP for typing of candida zeylanoides and Debaryomyces hansenii yeast strains isolated from cheese. Syst. Appl. Microbiol. 19, 255-264. doi: 10.1016/S0723-2020(96)80052-X

Ruderfer, D. M., Pratt, S. C., Seidel, H. S., and Kruglyak, L. (2006). Population genomic analysis of outcrossing and recombination in yeast. Nat. Genet. 38, 1077-1081. doi: 10.1038/ng1859

Ryu, S. L., Murooka, Y., and Kaneko, T. (1998). Reciprocal translocation at duplicated RPL2 loci might cause speciation of Saccharomyces bayanus and Saccharomyces cerevisiae. Curr. Genet. 33, 345-351. doi: 10.1007/ s002940050346

Sabate, J., Cano, J., Esteve-Zarzoso, B., and Guillamón, J. M. (2002). Isolation and identification of yeasts associated with vineyard and winery by RFLP analysis of ribosomal genes and mitochondrial DNA. Microbiol. Res. 157, 267-274. doi: 10.1078/0944-5013-00163
Salinas, F., Garrido, D., Ganga, A., Veliz, G., and Martínez, C. (2009). Taqman real-time PCR for the detection and enumeration of Saccharomyces cerevisiae in wine. Food Microbiol. 26, 328-332. doi: 10.1016/j.fm.2008.12.001

Salvadó, Z., Arroyo-López, F. N., Barrio, E., Querol, A., and Guillamón, J. M. (2011). Quantifying the individual effects of ethanol and temperature on the fitness advantage of Saccharomyces cerevisiae. Food Microbiol. 28, 1155-1161. doi: $10.1016 /$ j.fm.2011.03.008

Schuller, D., Valero, E., Dequin, S., and Casal, M. (2004). Survey of molecular methods for the typing of wine yeast strains. FEMS Microbiol. Lett. 231, 19-26. doi: 10.1016/S0378-1097(03)00928-5

Schütz, M., and Gafner, J. (1994). Dynamics of the yeast strain population during spontaneous alcoholic fermentation determined by CHEF gel electrophoresis. Lett. Appl. Microbiol. 19, 253-257. doi: 10.1111/j.1472-765X.1994.tb00957.x

Selma, M. V., Martínez-Culebras, P. V., Elizaquivel, P., and Aznar, R. (2009). Simultaneous detection of the main black aspergilli responsible for ochratoxin A (OTA) contamination in grapes by multiplex real-time polymerase chain reaction. Food Addit. Contam. Part A Chem. Anal. Control Expo. Risk Assess. 26, 180-188. doi: 10.1080/02652030802345623

Setati, M. E., Jacobson, D., Andong, U.-C., and Bauer, F. (2012). The vineyard yeast microbiome, a mixed model microbial map. PLoS ONE 7:e52609. doi: 10.1371/journal.pone.0052609

Setati, M.E., Jacobson, D., and Bauer, F.F. (2015). Sequence-based analysis of the Vitis vinifera L. cv Cabernet Sauvignon grape must mycobiome in three South African vineyards employing distinct agronomic systems. Front. Microbiol. 6:1358. doi: $10.3389 /$ fmicb.2015.01358

Sipiczki, M. (2008). Interspecies hybridisation and recombination in Saccharomyces wine yeasts. FEMS Yeast Res. 8, 996-1007. doi: 10.1111/j. 1567-1364.2008.00369.x

Solieri, L., Antúnez, O., Pérez-Ortín, J. E., Barrio, E., and Giudici, P. (2008). Mitochondrial inheritance and fermentative : oxidative balance in hybrids between Saccharomyces cerevisiae and Saccharomyces uvarum. Yeast 25, 485-500. doi: 10.1002/yea.1600

Stefanini, I., Albanese, D., Cavazza, A., Franciosi, E., De Filippo, C., Donati, C., et al. (2016a). Dynamic changes in microbiota and mycobiota during spontaneous 'Vino Santo Trentino' fermentation. Microb. Biotechnol. 9, 195-208. doi: 10.1111/1751-7915.12337

Steensels, J., Snoek, T., Meersman, E., Nicolino, M. P., Voordeckers, K., and Verstrepen, K. J. (2014). Improving industrial yeast strains: exploiting natural and artificial diversity. FEMS Microbiol. Rev. 38, 947-995. doi: 10.1111/15746976.12073

Stefanini, I., Dapporto, L., Berná, L., Polsinelli, M., Turillazzi, S., and Cavalieri, D. (2016b). Social wasps are a Saccharomyces mating nest. Proc. Natl. Acad. Sci. U.S.A. 113, 2247-2251. doi: 10.1073/pnas.1516453113

Stevenson, L. G., Drake, S. K., Shea, Y. R., Zelazny, A. M., and Murray, P. R. (2010). Evaluation of matrix-assisted laser desorption ionization-time of flight mass spectrometry for identification of clinically important yeast species. J. Clin. Microbiol. 48, 3482-3486. doi: 10.1128/JCM.00687-09

Stringini, M., Comitini, F., Taccari, M., and Ciani, M. (2009). Yeast diversity during tapping and fermentation of palm wine from Cameroon. Food Microbiol. 26, 415-420. doi: 10.1016/j.fm.2009.02.006

Strope, P. K., Skelly, D. A., Kozmin, S. G., Mahadevan, G., Stone, E. A., Magwene, P. M., et al. (2015). The 100-genomes strains, a S. cerevisiae resource that illuminates its natural phenotypic and genotypic variation and emergence as an opportunistic pathogen. Genome Res. 25, 762-774. doi: 10.1101/gr.185538.114

Takahashi, M., Masaki, K., Mizuno, A., and Goto-Yamamoto, N. (2014). Modified COLD-PCR for detection of minor microorganisms in wine samples during the fermentation. Food Microbiol. 39, 74-80. doi: 10.1016/j.fm.2013. 11.009

Tavanti, A., Davidson, A. D., Fordyce, M. J., Gow, N. A. R., Maiden, M. C. J., and Odds, F. C. (2005). Population structure and properties of Candida albicans, as determined by multilocus sequence typing. J. Clin. Microbiol. 43, 5601-5613. doi: 10.1128/JCM.43.11.5601-5613.2005

Taylor, M. W., Tsai, P., Anfang, N., Ross, H. A., and Goddard, M. R. (2014). Pyrosequencing reveals regional differences in fruit-associated fungal communities. Environ. Microbiol. 16, 2848-2858. doi: 10.1111/1462-2920. 12456

Tello, J., Cordero-Bueso, G., Aporta, I., Cabellos, J. M., and Arroyo, T. (2012). Genetic diversity in commercial wineries: effects of the farming system and 
vinification management on wine yeasts. J. Appl. Microbiol. 112, 302-315. doi: 10.1111/j.1365-2672.2011.05202.x

Tofalo, R., Schirone, M., Corsetti, A., and Suzzi, G. (2012). Detection of Brettanomyces spp. in red wines using real-time PCR. J. Food Sci. 77, M545-M549. doi: 10.1111/j.1750-3841.2012.02871.x

Torija, M. J., Rozès, N., Poblet, M., Guillamón, J. M., and Mas, A. (2001). Yeast population dynamics in spontaneous fermentations: comparison between two different wine-producing areas over a period of three years. Antonie Van Leeuwenhoek 79, 345-352. doi: 10.1023/A:1012027718701

Tornai-Lehoczki, J., and Dlauchy, D. (2000). Delimination of brewing yeast strains using different molecular techniques. Int. J. Food Microbiol. 62, 37-45. doi: 10.1016/S0168-1605(00)00356-1

Tredoux, H. G., Kock, J. L. F., and Lategan, P. M. (1987). The use of cellular longchain fatty acid composition in the identification of some yeasts association with the wine industry. Syst. Appl. Microbiol. 9, 299-306. doi: 10.1016/S07232020(87)80038-3

Urso, R., Rantsiou, K., Dolci, P., Rolle, L., Comi, G., and Cocolin, L. (2008). Yeast biodiversity and dynamics during sweet wine production as determined by molecular methods. FEMS Yeast Res. 8, 1053-1062. doi: 10.1111/j.1567-1364. 2008.00364.x

van Veen, S. Q., Claas, E. C. J., and Kuijper, E. J. (2010). Highthroughput identification of bacteria and yeast by matrix-assisted laser desorption ionization-time of flight mass spectrometry in conventional Medical Microbiology laboratories. J. Clin. Microbiol. 48, 900-907. doi: 10.1128/JCM.02071-09

Van Vuuren, H. J. J., and Meer, V. D. L. (1987). Fingerprinting of yeasts by electrophoresis. Am. J. Enol. Vitic. 38, 49-53.

Vancanneyt, M., Pot, B., Hennebert, G., and Kersters, K. (1991). Differentiation of yeast species based on electrophoretic whole-cell protein patterns. Syst. Appl. Microbiol. 14, 23-32. doi: 10.1016/S0723-2020(11)80357-7

Vaughan-Martini, A., and Martini, A. (2011). "Saccharomyces Meyen ex Reess (1870)," in The Yeasts: a Taxonomic Study. 5th Edn, eds C. P. Kurtzman, J. W. Fell,and T. Boekhout (London: Elsevier), 733-746.

Vendrame, M., Manzano, M., Comi, G., Bertrand, J., and Iacumin, L. (2014). Use of propidium monoazide for the enumeration of viable Brettanomyces bruxellensis in wine and beer by quantitative PCR. Food Microbiol. 42, 196-204. doi: 10.1016/j.fm.2014.03.010

Vigentini, I., De Lorenzis, G., Picozzi, C., Imazio, S., Merico, A., Galafassi, S., et al. (2012). Intraspecific variations of Dekkera/Brettanomyces bruxellensis genome studied by capillary electrophoresis separation of the intron splice site profiles. Int. J. Food Microbiol. 157, 6-15. doi: 10.1016/j.ijfoodmicro.2012. 02.017

Voordeckers, K., Brown, C. A., Vanneste, K., Van Der Zande, E., Voet, A., Maere, S., et al. (2012). Reconstruction of ancestral metabolic enzymes reveals molecular mechanisms underlying evolutionary innovation through gene duplication. PLoS Biol. 10:e1001446. doi: 10.1371/journal.pbio. 1001446

Vos, P., Hogers, R., Bleeker, M., Reijans, M., Van De Lee, T., Hornes, M., et al. (1995). AFLP: a new technique for DNA fingerprinting. Nucleic Acids Res. 23, 4407-4414. doi: 10.1093/nar/23.21.4407

Wagner, A. (1998). The fate of duplicated genes: loss or new function? Bioessays 20, 785-788. doi: 10.1002/(SICI)1521-1878(199810)20:10<785::AID-BIES2>3. $0 . \mathrm{CO} ; 2-\mathrm{M}$
Wang, C., García-Fernández, D., Mas, A., and Esteve-Zarzoso, B. (2015). Fungal diversity in grape must and wine fermentation assessed by massive sequencing, quantitative PCR and DGGE. Front. Microbiol. 6:1156. doi: 10.3389/fmicb.2015. 01156

Wang, Q. M., Liu, W. Q., Liti, G., Wang, S. A., and Bai, F. Y. (2012). Surprisingly diverged populations of Saccharomyces cerevisiae in natural environments remote from human activity. Mol. Ecol. 21, 5404-5417. doi: 10.1111/j.1365294X.2012.05732.x

Warringer, J., Zörgö, E., Cubillos, F. A., Zia, A., Gjuvsland, A., Simpson, J. T., et al. (2011). Trait variation in yeast is defined by population history. PLoS Genet. 7:e1002111. doi: 10.1371/journal.pgen.1002111

Welch, J. W., Fogel, S., Cathala, G., and Karin, M. (1983). Industrial yeasts display tandem gene iteration at the CUP1 region. Mol. Cell. Biol. 3, 1353-1361. doi: 10.1128/MCB.3.8.1353

Will, J. L., Kim, H. S., Clarke, J., Painter, J. C., Fay, J. C., and Gasch, A. P. (2010). Incipient balancing selection through adaptive loss of aquaporins in natural Saccharomyces cerevisiae populations. PLoS Genetics 6:e1000893. doi: 10.1371/ journal.pgen.1000893

Willenburg, E., and Divol, B. (2012). Quantitative PCR: an appropriate tool to detect viable but not culturable Brettanomyces bruxellensis in wine. Int. J. Food Microbiol. 160, 131-136. doi: 10.1016/j.ijfoodmicro.2012.09.012

Wolfe, K. H. (2004). Evolutionary genomics: yeasts accelerated beyond BLAST. Curr. Biol. 14, R392-R394. doi: 10.1016/j.cub.2004.05.015

Wolfe, K. H., and Shields, D. C. (1997). Molecular evidence for an ancient duplication of the entire yeast genome. Nature 387, 708-713. doi: 10.1038/42711

Wolters, J. F., Chiu, K., and Fiumera, H. L. (2015). Population structure of mitochondrial genomes in Saccharomyces cerevisiae. BMC Genomics 16:451. doi: 10.1186/s12864-015-1664-4

Yamamoto, N., Yamamoto, N., Amemiya, H., Yokomory, Y., Shimizu, K., and Totsuka, A. (1991). Electrophoretic karyotypes of wine yeasts. Am. J. Enol. Vitic. 42, 358-363.

Zhang, H., Richards, K. D., Wilson, S., Lee, S. A., Sheehan, H., Roncoroni, M., et al. (2015). Genetic characterization of strains of Saccharomyces uvarum from New Zealand wineries. Food Microbiol. 46, 92-99. doi: 10.1016/j.fm.2014.07.016

Zhao, Y., Strope, P. K., Kozmin, S. G., Mccusker, J. H., Dietrich, F. S., Kokoska, R. J., et al. (2014). Structures of naturally evolved CUP1 tandem arrays in yeast indicate that these arrays are generated by unequal nonhomologous recombination. G3 (Bethesda) 4, 2259-2269. doi: 10.1534/g3.114.012922

Zimmer, A., Durand, C., Loira, N., Durrens, P., Sherman, D. J., and Marullo, P. (2014). QTL Dissection of lag phase in wine fermentation reveals a new translocation responsible for Saccharomyces cerevisiae adaptation to sulfite. PLoS ONE 9:e86298. doi: 10.1371/journal.pone.0086298

Conflict of Interest Statement: The authors declare that the research was conducted in the absence of any commercial or financial relationships that could be construed as a potential conflict of interest.

Copyright (C) 2017 Guillamón and Barrio. This is an open-access article distributed under the terms of the Creative Commons Attribution License (CC BY). The use, distribution or reproduction in other forums is permitted, provided the original author(s) or licensor are credited and that the original publication in this journal is cited, in accordance with accepted academic practice. No use, distribution or reproduction is permitted which does not comply with these terms. 